\title{
Understanding firm exit: a systematic literature review
}

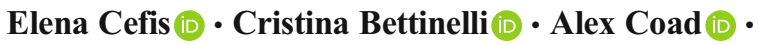 \\ Orietta Marsili $[$ (i)
}

Accepted: 16 February 2021 / Published online: 18 May 2021

(C) The Author(s) 2021

\begin{abstract}
We investigate the corpus of literature on firm exit by means of a systematic literature review (SLR) which yields a final sample of 142 journal articles for the period 1991-2020. The phenomenon of firm exit is explored from a variety of perspectives: business exit; exit at the individual entrepreneur level; exit from specific markets; exit from foreign markets; and the role of exit for industrial dynamics conceived more broadly. Special attention is given to the various exit routes, including voluntary liquidation, mergers and acquisitions (M\&A), initial public offerings (IPO), and of course bankruptcy. The SLR sets the scene for the Special Issue papers that are presented towards the end, and we conclude with some suggestions for future research.
\end{abstract}

The Plain English Summary This article develops a systematic literature review around three decades of firm exit research, patterns, developments, and intriguing gaps. In this paper, we systematically review 142 studies on firm exit from various perspectives, identify major patterns, and outline the debate around firm exit. We propose reflections useful for scholars willing to engage in firm exit research in the future and set the scene for the special issue papers. Overall, this work

E. Cefis $(\square)$

University of Bergamo, Bergamo, and Sant'Anna School of Advanced Studies, Pisa, Italy

e-mail: elena.cefis@unibg.it

C. Bettinelli

University of Bergamo, Bergamo, Italy shows the remarkable progress made in the area of firm exit that has evolved from the view of exit as a homogenous event signaling failure to a vision of exit as a heterogenous event. Exploring the sources of heterogeneity of exits from various perspectives could offer promising paths for future research.

Keywords Firm exit · Closure · M\&A · Bankruptcy · Exit routes $\cdot$ Industrial dynamics $\cdot$ Survival

JEL classification C14 - C20 · D22 - D24 · G33 - G34 · $\mathrm{L} 25 \cdot \mathrm{L} 26 \cdot \mathrm{M} 13 \cdot \mathrm{O} 30 \cdot \mathrm{O} 31 \cdot \mathrm{O} 34 \cdot \mathrm{O} 47$

\section{Introduction}

Firm exit is a central topic of academic and economic interest, especially in periods of economic turmoil where exit can both shape (Guerrieri et al., 2020) and be shaped (Bartik et al., 2020) by wider macroeconomic dynamics. Thus, understanding firm exit is important both for firms in competitive contexts as well as the economy in general (DeTienne, 2010, DeTienne \& Wennberg, 2015).

\author{
A. Coad \\ Waseda Business School, Waseda University, Tokyo, Japan \\ O. Marsili \\ School of Management, University of Bath, Bath, UK
}


The importance of firm exit is indicated by a wide literature which studies a variety of related aspects (Wennberg \& DeTienne, 2014). Some scholars have focused on the possible antecedents of firm exit such as inertial forces and internal selection environment (Burgelman, 1994), performance levels (Chang, 1996), the presence of different types of uncertainty (Gaba \& Terlaak, 2013), the role of innovation (e.g., Cefis \& Marsili, 2005, 2012, 2019), of financial constraints (Ponikvar et al., 2018), of different ownership types (e.g., Chirico et al., 2020), or of specific seller motives (Graebner \& Eisenhardt, 2004). Others have instead studied the process of firm exit considering both internal and external forces (e.g., Bradley et al., 2011; de Figueiredo \& Silverman, 2007; Leroy et al., 2015; Ebert et al., 2018; Schary, 1991) or where exit is seen as the complementary status of survival (e.g., Cefis \& Marsili, 2005; Coad et al., 2013; Coad \& Guenther, 2013; de Figueiredo \& Silverman, 2012; Yang \& Aldrich, 2012). Still others have investigated the factors affecting the time and the route to exit of ventures that are already distressed (Balcaen et al., 2011, 2012; Yamakawa \& Cardon, 2017). Some attempts to review this wide literature have been done in the past: literature reviews exist on exit in general (Parastuty, 2018) or with a focus on some aspects of exit such as divestitures (Decker \& Mellewigt, 2007), entrepreneurial exit (Wennberg \& DeTienne, 2014), and small business exit (Wennberg \& DeTienne, 2014); or again, on firm survival (Josefy et al., 2017; Soto-Simeone et al., 2020). The past decades have seen a blossoming of studies investigating the exit phenomenon through the concept of "firm exit." This has led to a rather splintered and fragmented understanding of the concept. Often departing from seminal conceptualizations, research on firm exit has expanded in multiple directions, leading to mixed approaches and findings. Thus, the need for a review and clarification is especially urgent, especially in the current economic period where firm exit is becoming a core theme.

This paper provides a systematic literature review (SLR) of papers on firm exit published in the last three decades. We offer at least three major contributions. First, with our systematic analysis, we represent an updated overall understanding of the state of the art for studies focusing on the concept of "firm exit" identifying the major thematic areas that have populated the academic debate so far. Second, we depict the development of this body of knowledge by showing how the structure of the field has evolved over time. Third, we discuss some key recommendations and offer promising directions for future research.

\section{Method}

To provide an overview of the state of the art on firm exit, we produced a systematic review (Greenhalgh, 1997). To select relevant articles, we followed the protocol illustrated in Fig. 1.

More specifically, following the practice in our field (e.g., Urbano et al., 2019), we relied on the bibliometric database ISI Web of Science ${ }^{\circledR}$ and applied a query with the following keywords: "firm* exit" OR "exit of firm*" OR "business* exit" OR "exit of business*" OR "mod* of exit" OR "form* of exit" should appear either in the title, in the article's keywords, or in the abstract. We considered all the articles published up until the end of January 2020 . To be as representative as possible we did not set any start date. This led to a total of 363 articles. We then limited our focus to articles in journals ranked 3 stars or above by the Association of Business SchoolsABS Academic Journal Guide 2018 (Atewologun et al., 2017), obtaining 178 articles. Finally, the title, keyword, abstract, and (when necessary) the full text of each article were examined to determine whether it was relevant for our review. In case of doubt about the relevance, two of the authors discussed the contents and took a decision about inclusion/exclusion. This process led to a final database of 142 articles. The first article that was registered in WOS and matched our query was published in 1991 (Afuah and Utterback). ${ }^{1}$

\subsection{Description of the studies in our sample}

We categorized each article as empirical, conceptual, or a literature review; we also mapped the type of empirical studies performed (qualitative, quantitative, or both), the nature of the sample (size, whether longitudinal or not, country, sector), the major theory or perspective used,

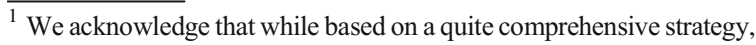
our query in Web of Science may have led to the exclusion of some papers either because the focus was on papers using "firm exit" as a keyword (regardless of other possible sub-themes or keywords) or because Web of Science may have excluded some papers published before the digitalization of journals, or again because their journals were not registered in Web of Science. However, we are quite confident that, despite these limitations, our review is comprehensive enough to develop the major developments of the literature on firm exit.
} 
STEP 1. Search on ISI Web of Science ${ }^{\circledR}$ the following keywords related to firm exit:

"firm* exit" OR "exit of firm*" OR "business* exit" OR "exit of business*" OR "mod* of exit" OR "form* of exit"

These keywords must be present in the title or in the papers key-words, or in the abstract.

Time boundary: all paper published in academic journals before the $29^{\text {th }}$ of January 2020

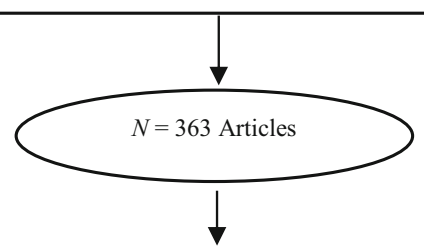

STEP 2. Confine the search to articles published in journals listed in the Chartered Association of Business Schools’ Academic Journal Guide (2018) - ABS Academic Journal Guide with 3, 4, and 4* stars

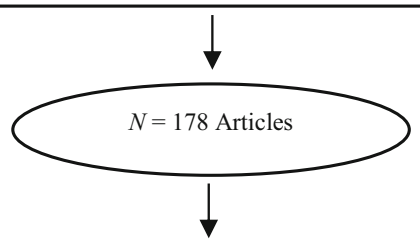

STEP 3. Divide remaining articles into two categories: papers relevant to the research objective and papers nonrelevant. Read and discuss the papers for which there are doubts.

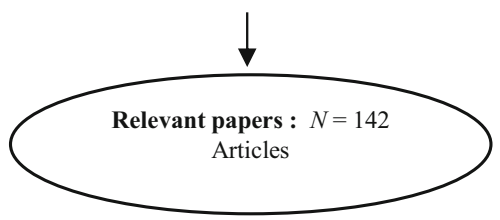

Fig. 1 Search procedure for selecting articles on firm exit

the definition of exit, and the role of exit (whether a driver, an outcome, or a contextual variable).

As shown in Table 1, the academic debate on exit has captured the attention of a variety of academic outlets, with Small Business Economics and Strategic Management Journal being the journals with the highest concentration of papers. Excluding the case of these two journals, we can say that papers on exit have been published in diverse journals with variegated backgrounds and from different disciplines.

As far as methodological approaches are concerned, our analysis revealed that the majority of articles was empirical (94), while one was a literature review (Decker \& Mellewigt, 2007), and the remaining papers were either purely conceptual, or theoretical including mathematical models (e.g., Egger et al., 2012), or again, including simulations and/or calibrations (e.g., Webber et al., 1992). Among the empirical articles, 4 were qualitative, the vast majority was quantitative (88), and only two (Sillanpää \& Laamanen, 2009; Higgins et al., 2015) used a mixed-methods approach. Of the quantitative papers, 76 were based on longitudinal observations and large databases, which confirms the richness of data gathered so far on firm exit.

As Table 2 shows, the empirical studies had been developed in very different geographical contexts, ${ }^{2}$ with most focusing on single European countries (36 articles), the USA (19), and single Asian countries (9). Latin American and African countries were quite underrepresented. A wide array of industries was represented, 23 were indeed the studies that considered all available firms with no sectorial filters, in addition, there is a clear overrepresentation of studies focused on some or all the

\footnotetext{
${ }^{2}$ We mapped the geographical origins both for the purely empirical papers and for the theoretical papers that included simulations/
} calibrations with real data. 
Table 1 Articles by journal

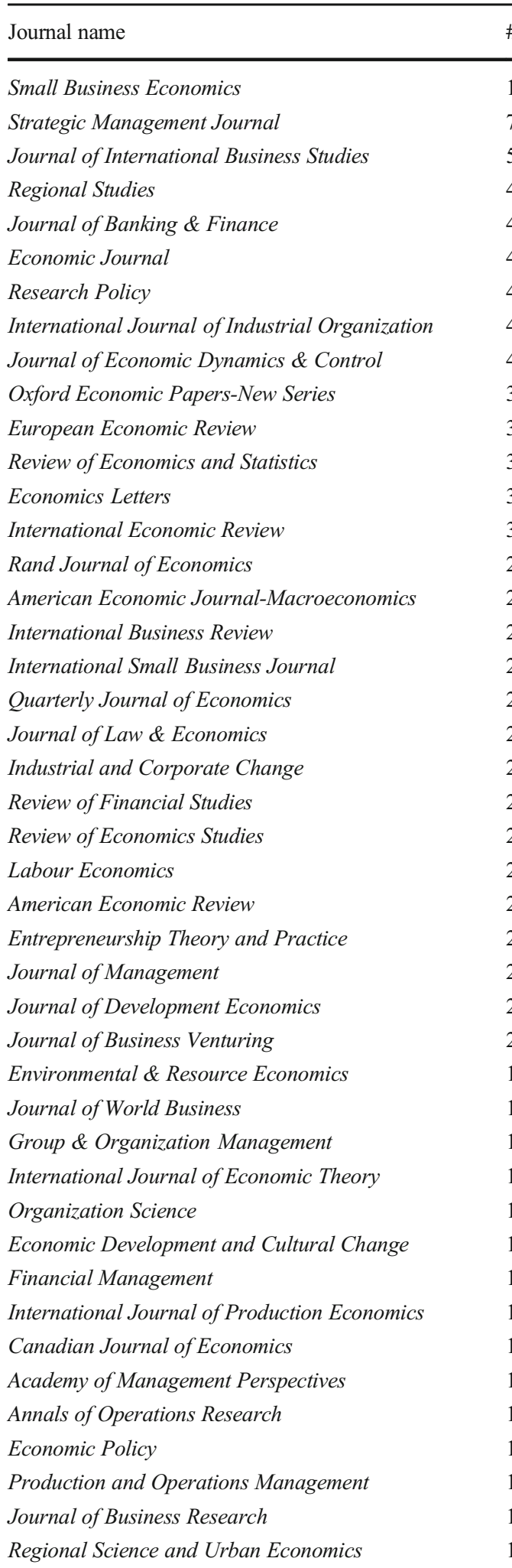

Table 1 (continued)

\begin{tabular}{|c|c|}
\hline Journal name & \# papers \\
\hline Technological Forecasting and Social Change & 1 \\
\hline Financial Review & 1 \\
\hline Technovation & 1 \\
\hline Business History & 1 \\
\hline Journal of Corporate Finance & 1 \\
\hline Ecological Economics & 1 \\
\hline Economic Theory & 1 \\
\hline Kyklos & 1 \\
\hline Journal of Econometrics & 1 \\
\hline Management International Review & 1 \\
\hline Journal of Economic Behavior \& Organization & 1 \\
\hline Environment and Planning $A$ & 1 \\
\hline Economica & 1 \\
\hline Progress in Human Geography & 1 \\
\hline Journal of Financial and Quantitative Analysis & 1 \\
\hline British Journal of Management & 1 \\
\hline American Journal of Agricultural Economics & 1 \\
\hline European Journal of Operational Research & 1 \\
\hline Journal of International Economics & 1 \\
\hline Review of Economic Dynamics & 1 \\
\hline Journal of International Marketing & 1 \\
\hline Food Policy & 1 \\
\hline Energy Economics & 1 \\
\hline Review of Income and Wealth & 1 \\
\hline Entrepreneurship and Regional Development & 1 \\
\hline Strategic Entrepreneurship Journal & 1 \\
\hline Journal of Marketing & 1 \\
\hline Strategic Organization & 1 \\
\hline Journal of Monetary Economics & 1 \\
\hline Journal of Political Economy & 1 \\
\hline Academy of Management Journal & 1 \\
\hline Journal of Conflict Resolution & 1 \\
\hline
\end{tabular}

manufacturing sectors (27), while much less accentuated was the focus on services firms (9), or on manufacturing and services together (8). The remaining empirical papers considered instead specific cases such as nonprofit firms (Gras \& Mendoza-Abarca, 2014), deregulated industries (Ovtchinnikov, 2013), or family firms (Akhter et al., 2016). ${ }^{3}$

In terms of theoretical approach, different types of recurrent theories and/or perspectives are adopted in the studies considered, most of them grounded in econom-

\footnotetext{
${ }^{3}$ In two papers the sector was not specified.
} 
ics such as Schumpeterian/evolutionary (Lööf \& Heshmati, 2002; Luo, 2009), neoclassical (e.g., Golombek \& Raknerud, 2018), labor market (e.g., Bhaskar \& To, 1999) and industrial organization perspectives (e.g., Kumar \& Zhang, 2019). Other recurrent perspectives were the resource-based view and dynamic capabilities (e.g., Bruyaka \& Durand, 2012), resource dependence theory (e.g., Gras \& Mendoza-Abarca, 2014), and internationalization theories (e.g., Colantone \& Sleuwaegen, 2010). In various instances, scholars preferred to rely on specific exit and survival literature rather than on theories and perspectives (e.g., Goktan et al., 2018). Where possible, we also distinguished papers based on their unit of observation, not surprisingly the vast majority (82) focused on firms (e.g., Bernard et al., 2017; Furr \& Kapoor, 2018), 9 on sectors (e.g., Johansson, 2005), and 6 focused on countries, regions, or provinces (e.g., Bosma et al., 2011).

It is worth noting that this literature (regardless of the method used) is strongly skewed towards considering firm exit as an outcome, while studies considering exit as a driver (e.g., Armand \& Mendi, 2018) or as a contextual variable (e.g., Benabou, 1992; Heijdra \& Ploeg, 1996; Raknerud et al., 2007; and Capasso et al., 2015) were less present. As our query clearly shows, our aim is to depict a picture of the debate around the concept of "firm exit." As we will show in the next section, scholars focusing on firm exit mainly developed the business exit theme; interestingly, however, other themes developed around the debate on firm exit such as firm exit and the individual, firm exit as market exit, and firm exit from a foreign market. Finally, we dedicate a section to all studies that used the concept of firm exit and studied exit and market dynamics considering the competitive/market process (by generally relying on theoretical/mathematical models such as general equilibrium).

\section{A survey of firm exit}

\subsection{Exit as business exit}

Exit can be a process that refers to the exit of a business, a firm or a corporation from the market. Several patterns emerge in this literature. The main difference among the articles analyzed in this section is whether firms' exit has been considered a homogeneous phenomenon, or different forms of exit have been recognized as distinct phenomena with different economic/business meaning.
Table 2 Articles by geographic focus (only empirical)

\begin{tabular}{ll}
\hline Geographic focus & Number of studies \\
\hline Single EU country & 36 \\
US & 19 \\
Single Asian country & 9 \\
Various EU countries & 5 \\
Single Latin American country & 4 \\
UK & 4 \\
Global & 4 \\
Single African country & 3 \\
Single US state & 3 \\
Canada & 3 \\
Latin American countries & 1 \\
Australia & 1 \\
Pakistan & 1 \\
Developing countries & 1 \\
Total & 94 \\
\hline
\end{tabular}

Finally, we discuss some of the major patterns of this literature.

\subsubsection{Different conceptualizations of exit}

\section{Exit as a homogeneous phenomenon}

The studies where exit is treated as a homogeneous process are generally the oldest ones, or those that rely on limited data sources. Indeed, especially in the National Statistical Offices (and forcefully also in other data sources reporting firms' exit), the availability of data on exit types came much more recently (see for example the Italian National Statistical Office where different types of firms' exit began to be registered around 2009-2010), and, therefore, the studies on firms' exit were generally focused on a homogeneous type of exit. Although the focus of these articles is the exit of firms from the market, the way in which firms' exit has been proxied or measured varies greatly.

In particular, exit is defined as follows:

- General exit by all forms, without distinguishing among different forms of exits, including exit via M\&A, closure, bankruptcy, and sell-off (Bennmarker et al., 2009; Fafchamps \& Schündeln, 2013; Saridakis et al., 2013; Fraisse et al., 2018; Cerqueiro et al., 2019) 
- Firm's voluntary liquidation (or more frequently called "closure") initiated by the firm's owner; it is also named firms' closure or firms' death (Santarelli et al., 2009; Colantone \& Sleuwaegen, 2010; Camacho \& Rodriguez, 2013; Varum et al., 2014; Golombek \& Raknerud, 2018; Martinez et al., 2019)

- Firms' deregistration (Coucke \& Sleuwaegen, 2008; Klapper \& Richmond, 2011; Varum \& Rocha, 2012; Gras \& Mendoza-Abarca, 2014; Arbia et al., 2014; Carreira \& Teixeira, 2016; Basile et al., 2017). The deregistration can be from an official Business Register held and elaborated by National Statistical Offices (as in Cefis \& Marsili, 2006) or it could be a "deregistration" from other commonly used datasets, such as Bureau van Dijk's Orbis, Amadeus, or Aida that report the records from firms' financial statements. In these latter cases, researchers infer the exit of the firms making assumptions regarding firms' behavior, like stopping production operations for a certain time period (Jensen \& Miller, 2018; Kumar \& Zhang, 2019) or not registering in Orbis or Amadeus any sales or assets for more than a few consecutive years. For example, in Bennett and Hall (2020), "deregistration" from Orbis is considered when no sales and no assets were recorded for at least 3 consecutive years. In another case, Fraisse et al., (2018, p. 159) "define firm exit as a situation where a firm disappears simultaneously from the credit register and from the file containing firms' annual financial statements." It should be noted that the papers that use deregistration from one or more registers in order to define exit do not distinguish between the different modes of exit, so deregistration could mean bankruptcy, closure, or acquisition.

- Firms' forced liquidation (or "bankruptcy") not initiated by the owner. There are few papers that defined firms' exit as a forced liquidation not initiated by the owner (Hansen \& Ziebarth, 2017; Aga \& Francis, 2017) in which, however, the forced liquidation is mostly seen as synonyms of closure, or as a removal from the court register without carrying out the liquidation procedure (Ponikvar et al., 2018)

- Firms' sell-off/divestiture (or "acquisition" if the perspective of the acquiring firms is adopted) when firms (or parts thereof) are sold to an external organization instead of being closed (Zheng et al., 2017). Among our articles, we find a literature review on firms' exit by divestiture by Decker and Mellewigt (2007) that focuses on the antecedents of, barriers to, and outcomes of business exit as an important corporate change initiative that emphasizes that business exit should not be seen as an outcome of de-conglomeration, but rather as a part of strategic change and internal reconfiguration, bringing the attention on the seller's side in a divestiture. The same trajectory has been explored by the only case study among our SRL papers that deals with exit as a divestment of business units. Salvato et al. (2010) study the Falck group, presenting the critical role of exiting a business from an industry to pursue novel entrepreneurial opportunities in another industry and to enable longevity and success of family firms. Conversely, always regarding family firms, Akhter et al. (2016) find that business families may prefer to shut down a satellite business rather than sell it due to identity considerations. The same type of reasoning of Salvato et al. (2010) has the article by Decker and Mellewigt (2012) where its purpose is to examine the potential of business exit for initiating a strategic change in divesting parent firms.

\section{Different types of exit}

Growing data availability and diffused awareness that "exit $\neq$ failure" have stimulated research that distinguishes between exit routes (Wennberg et al., 2010). A seminal paper (Schary, 1991) emphasized at least three different ways of firms' exit, through M\&A, voluntary liquidation, or bankruptcy, which have important economic differences that previous work has overlooked treating exits as a homogeneous phenomenon. She develops a model of the relation between the forms of exit and concludes that "there is some heterogeneity across forms of exit, and that information about the characteristics of the firm alone is not sufficient to predict all forms of exit" (Schary, 1991, p. 339).

Among our SLR papers, the first paper that dealt with different types of exit was Clark \& Wrigley (1997). It is based on 81 plants of large multinationals and studies outcomes of survival, voluntary liquidation, and bankruptcy/liquidation.

More recently, research began to differentiate only between two types of exit, like exit by bankruptcy vs sell-off (Bhattacharjee et al., 2009), or closure vs sell-off (Dimara et al., 2008; Bruyaka \& Durand, 2012; Fortune \& Mitchell, 2012), and subsequently, 
the articles dealt with different types of exit in a more detailed way.

Usually, the different types of exit have been treated as independent competing risks of exit, assuming that the probability of one exit route is independent from the others. For example, the probability of exiting by closure is independent from the probability of exiting by bankruptcy and/or acquisition. This strong assumption has generally been made to enable estimation via competing risk models with the data available, rather than reflecting any deeper theoretical assumptions or reasoning.

The articles in our review consider different combinations of firms' exits, focusing on the following:

- Closure vs sell-off (Bruyaka \& Durand, 2012)

- Closure vs M\&A (Weterings \& Marsili, 2015)

- Closure vs sell-off (Fortune \& Mitchell, 2012)

- Closure vs M\&A vs radical restructuring (Cefis \& Marsili, 2012)

- Bankruptcy vs sell-off (Bhattacharjee et al., 2009; Goktan et al., 2018)

- Bankruptcy vs closure vs M\&A (Balcaen et al., 2012)

- Bankruptcy vs closure vs M\&A vs forced liquidation (Ponikvar et al., 2018)

\section{"General" exit versus exit via $M \& A$}

Since the beginning of discussions surrounding exit routes, exit via M\&A attracted the attention of scholars, because it was clear that M\&A may have quite a different economic meaning than closure or bankruptcy. Exit via acquisitions (or sell-off) could be considered a positive (if not a profitable) way to exit in contrast to the other forms more "neutral" (voluntary liquidation or closure, when the ownership decides to close down for individual reasons - owner retirement, divorce, etc.- or because the business is not sufficiently satisfying) or more negative types of exit like bankruptcy and forced liquidation (Coad, 2014). Especially for young and small firms, exit via M\&A could be a "harvest" strategy aiming to cash in the profits due to an initial period of life where the firm has thrived and grown to the extent to become an attractive target for larger firms. Some articles have indeed investigated how factors such as innovation, employment growth, legal form (corporation vs sole proprietorship (Cotei \& Farhat, 2018)), managerial and functional organizational capabilities (Fortune \& Mitchell, 2012), and technical and scale efficiency (Dimara et al., 2008) can explain the firms' exit by M\&A versus closure (voluntary and involuntary). Furthermore, when considering large firms, if a sell-off of a subsidiary is done in favorable circumstances, the selloff can be interpreted as a strategic change for restructuring or refocusing the firm (Salvato et al., 2010; Decker \& Mellewigt, 2012). Finally, M\&A, and more precisely acquisitions (strategic acquisitions and private sales), have been investigated as an alternative exit route alongside IPO (Albert \& DeTienne, 2016; Chemmanur et al., 2018; Qi et al., 2015) in order to find out what are the determinants that increase the likelihood that private firms exit by going public rather than being acquired.

\subsubsection{Major developed patterns}

Various patterns emerge, notably as follows: (a) the one in which papers aim to identify the determinants of exit and (b) the other in which articles assess the influence/ the effect of a certain factor on firms' exit.

a. The papers centered on the identification of the determinants of firms' exit revolve around the idea that many factors can influence firms' exit, and they try to deduce the main and more important factors through usually an applied econometric study into which determinants are relevant (Frazer, 2005; Aga \& Francis, 2017; Golombek \& Raknerud, 2018; Chemmanur et al., 2018; Cotei \& Farhat, 2018). In this area, we find papers that set their analysis in a particular macro-economic period, i.e., during a severe recession (Carreira \& Teixeira, 2016), or during a particular phase of the firms' life, i.e., when firms are in economic distress due to their own characteristics and management (Balcaen et al., 2012; Dawley et al., 2002) or again in a particular geographic area (Ponikvar et al., 2018; Arbia et al., 2014).

b. The other group of papers, instead, starts from theoretical backgrounds/theories that suggest which specific factors have an influence on firms' exit. Therefore, they usually elaborate on the theoretical backgrounds to support the claims of such theories making empirical studies generally based on single macro-sectors (usually manufacturing) and on single countries.

The factors that have been mostly tested can be 
further divided into two broad classes: (i) micro factors, i.e., characteristics of the firms that affect their exit or survival; and (ii) macro factors, i.e., characteristics of the external environment that increase firms' exit or enhance firms' survival.

Furthermore, we can distinguish between micro and macro factors that influence firms' exit.

\section{Micro factors.}

Among the major micro factors, we can find the following:

- Technical and scale efficiency. Dimara et al. (2008) ask whether productive efficiency influences survival in the food sector, finding that high technical efficiency increases the median survival time and lowers the hazard rate of exit, while a competitive scale of operation, at or near to constant returns to scale, maximizes survival time.

- Innovation. Cefis and Marsili $(2006,2012)$ find that innovation carried out inside the firm matters for survival. There exists an innovation premium in terms of survival that is larger for young and small firms. In addition, product and process innovation are equally important to lower the probability to close down activities, especially if they are pursued in combination.

- Legal form. Cotei and Farhat (2018) investigate whether a particular legal form (especially corporations vs sole proprietorship) affects firms' exit, finding that businesses organized as corporations had very different acquisition outcomes than those organized as sole proprietorships, due to differences in innovation and growth potential in the startup years as well as throughout the business' lifetime. Young innovative and/or fast-growing corporations with external equity investors are more likely to become M\&A targets than sole-proprietorship firms.

- Corporate governance. Goktan et al. (2018) examine how corporate governance affects the probability of a corporation being acquired, going private, or going bankrupt. They show that "corporate governance features are more important determinants of the form of a firm's exit than many economic factors that have figured prominently in prior research" (p. 209).

Within this class (micro factors that affect firms' exit), we should place the literature that discusses and tested the different types of liabilities that hinder firms' survival.
- The liability of newness. Stinchcombe (1965) theorized that new organizations suffer from the liability of newness, having a higher probability to exit the market than older firms, due to lack of resources and lack of stable relations internally and externally to the firm (Freeman et al., 1983; Bruderl et al., 1992). Among the papers taken into consideration, we find few that explicitly address the problem of surviving in the first years. Cefis and Marsili (2006) find that young and small firms are the most exposed to the risk of exit, but also those that benefit most from innovation to survive in the market.

- The liability of smallness. It also concerns the new organizations and asserts that small new firms have a higher probability to exit the market than large new firms due to the fact that large firms have larger resources (including financial ones) that help them to overcome the difficulties in the early periods after entry (Baum, 1996 for a survey). In our survey, Varum and Rocha (2012) question whether the liability of smallness applies also during economic crises suggesting that large firms suffer a greater increase in exit hazard during downturns than smaller firms do, although small firms remain generally more likely to exit. Kim et al. (2015) analyzing a large sample of small firms during the 1997-1998 Korean economic crisis show the devastating impact of the crisis on small firms especially on those that had foreign liabilities prior to the crisis. Klapper and Richmond (2011) confirm that also in an African Country-Ghana - the probability of survival of new firms increases with firm size and the level of GDP.

The role of the liability of newness and smallness (explored mainly in the organization theory literature) is intrinsically linked to the role played by respectively firms' age and size in explaining firms' survival. The empirical industrial literature (see, e.g., Geroski, 1995; Sutton, 1997; Caves, 1998) has highlighted "stylized facts" that relate the probability of firms' survival with their age and size.

Concerning the role of age in the firm's exit process, there are several studies (Dunne et al., 1988; Mata \& Portugal, 1994; Audretsch, 1995; Baldwin, 1995) that show that age plays a major role in firms' survival, particularly in the first years of their existence. New firms (mainly entrepreneurial firms as opposed to spinoffs from large firms) have much higher probability to 
exit the market soon after entry (Audretsch \& Mahmood, 1994; Wagner, 1994) and a decreasing hazard rate to exit while aging (Baldwin \& Gorecki, 1991; Mata et al., 1995). Among the papers in our review, we find that Sakai et al. (2010), analyzing a sample of bankdependent small firms in Japan, find that firms' borrowing costs evolve as firms age and those firms with a lower quality profile are eventually forced to exit. Saridakis et al. (2013), for all sectors in the UK (excluding retail), investigate the impacts of financial constraints in the first year of firms' existence on firms' hazard to exit, showing that financially constrained start-ups have a higher probability to exit given that the liquidity constraints make the new firms more vulnerable to external shocks and therefore more likely to exit the industry.

Regarding the role of size, there were previous studies that showed robust evidence that there exists a strong inverse relationship among the current size of all firms and the probability to exit the market (Evans, 1987; Hall, 1987). They argue that there is a substantial difference between large and small firms in terms of probabilities to exit, because small firms are more likely to operate below the minimum efficient scale and therefore more likely to exit the market. Adopting the perspective that there exists a radical difference in survival probability between small and large firms, due essentially to larger availability of different kinds of resources, we find among our articles those concentrating only on quoted firms (Dawley et al., 2002; Bhattacharjee et al., 2009; Goktan et al., 2018; Ovtchinnikov, 2013), and others only on small firms (Kim et al., 2015; Sakai et al., 2010).

A class of firms that has been often analyzed separately, because of its peculiar characteristics and because they suffer from the liability of smallness and the liability of newness, are the entrepreneurial firms/start-ups defined in terms of being small and young (Basile et al., 2017; Chemmanur et al., 2018; Cotei \& Farhat, 2018).

\section{Macro factors.}

Among the major macro factors discussed in the papers, we can find the following:

- Environmental regulations. The effects of environmental regulations on the exit decisions of establishments are explored by Biørn et al. (1998), who find, surprisingly, that, in two out of three sectors they have studied, "establishments under strict environmental regulations had a lower tendency to exit than did establishments under weak or no environmental regulation." (p. 35), concluding that strict environmental regulations do not kill off firms, but may actually benefit them.

- Regional characteristics. Weterings and Marsili (2015) and Basile et al. (2017) investigate whether the regional characteristics influence the likelihood of firms' exit. The former article finds that high regional density of firms in an industry is associated with a lower probability to exit by closure and higher probability to exit by M\&A. And the latter shows that industry variety reduces the likelihood of firm exit, although the localization economies positively influence firm survival only in services sectors.

- Credit/bank access. Firms' capacity to access financial/bank credit has an effect on firms' exit, since exit can be a consequence of difficulties to access credit in a poor local financial development (Fafchamps \& Schündeln, 2013) or when the bank credit decreases due to the effect of a merger between two large banks that affects credit market competition (Fraisse et al., 2018).

- Financial Crisis. Special attention has been given to the effects of the financial/economic crisis on firms' exit. Kim et al. (2015) study the effect of the Korean crisis in 1997-1998 on small firms holding foreigncurrency-denominated debt. Carreira and Teixeira (2016) investigate the determinants of market selection mechanism in severe recessions as the financial crisis (2007-2008); Martinez et al. (2019) examine the impact of the financial crisis (2007-2008) on firms' failure in manufacturing and service sectors separately. Generally, financial/economic crises increase the probability of firms' exit; however, the magnitude of the increase is different among different sectors, among different time periods, and among different types of exit.

- Socio-economic jolts. More in general, the effects of socio-economic environmental jolts on the firms' exit were taken into consideration, as in Kumar and Zhang (2019) who explore the effects of productivity and demand shocks on exit. Finally, the role of macroeconomic instability on firms' exit is discussed by Rozo (2018) and by Bhattacharjee et al., (2009). The latter find that macroeconomic instability has opposing effects on bankruptcy hazard and acquisition hazard, raising the former and lowering the latter. 


\subsection{Firm exit and the individual}

Some literature on firm exit has explored the relationship between firm exit and individual behavior. In particular, a stream of research has focused on the decisionmaking process leading to firm exit, exploring the implications of the attitudes and characteristics of the stakeholders involved. These are foremost managers (Harada, 2007) and entrepreneurs (Cho \& Orazem, 2020), whose decision to dissolve a company reflects not only the poor performance of the firm but also their own demographic characteristics, like age and gender (Harada, 2007) and individual risk preferences (Cho \& Orazem, 2020). Economic difficulties, compared to other non-economic reasons, play a greater role in the closure of individual proprietorships and the dissolution of corporations when managers are younger, male, and less experienced (Harada, 2007). Closure driven by poor economic performance early in the life course of startups (within 6 years from birth) is associated with entrepreneurs that were more risk-averse at the time of founding, compared to the entrepreneurs of surviving start-ups. The latter, however, became more risk-averse over time with the success of the business (Cho \& Orazem, 2020). While the evidence based on survey data suggests that the risk preferences of entrepreneurs change over time as the business becomes established, evidence from an experimental setting indicates that the experience of monetary gains or losses before firm exit will frame risk perception and the probability to re-enter entrepreneurship. Consistent with prospect theory, entrepreneurs who lost money in their previous venture are more likely to re-enter because of loss aversion, although this effect fades away when the individual's self-efficacy is high (Hsu et al., 2017). In addition to the entrepreneur's individual attributes, the decision to exit reflects the influences of external stakeholders. Primarily for start-ups, venture capital investors play a key role in the timing and mode of exit through IPO or sell-off. VC funding offers a remedy to the presence of information asymmetries in the evaluation of novel business opportunities, mitigating the difficulty of entrepreneurs to access more conventional forms of funding. These same information asymmetries, however, may limit the option of an exit by IPO only to the best-performing ventures and restrict the set of potential buyers in an exit by sell-off to established companies and investors with industry-specific experience (Amit et al., 1998).

\subsection{Exit as a specific market exit}

Studies focusing on specific industries have examined the determinants of intra-industry variety in the propensity or rate of market exit at various levels of observation: across individual firms (Dixit \& Chintagunta, 2007), geographic regions (Buzzelli, 2005) and over time, in correspondence of an economic slowdown (Kalafsky \& MacPherson, 2006) and of other external shocks on market demand (Beaudin \& Huang, 2014). As a response to differences in market attractiveness across regions, exit is influenced by demand growth and, more broadly, by demographic factors, such as population density and immigration rates, and socioeconomic factors, such as income, unemployment, and home ownership (Buzzelli, 2005). Individual firm-level variables exert an important role in attenuating or accentuating the impact of exogenous shocks on exit rates, since smaller operations (Beaudin \& Huang, 2014) and those serving more localized markets (Kalafsky \& MacPherson, 2006) appear to be more adversely affected. When accounting for both firm-specific and marketspecific factors, the speed at which individual firms gain market information and update their expectations about the unknown market attractiveness can be as powerful a factor affecting the exit rate as the actual market factors (Dixit \& Chintagunta, 2007). Other studies have taken a broader approach, by examining market exit (defined as the "discontinuation" of a business operating in a specific location) across the whole economy, including manufacturing and services, in relation to socioeconomic environmental conditions. A study using a natural experiment in Mississippi affecting the banking system in 1930 shows that while the financial distress of banks and trade creditors during the Great Depression increased the rate of business exit, it did not increase the bankruptcy rate (Hansen \& Ziebarth, 2017). In a study of manufacturing firms in Columbia, higher rates of business exit were observed in those municipalities experiencing higher rates of armed conflict (Camacho \& Rodriguez, 2013), indicating that social as well as economic unrest discourage firms from staying in the market.

Market exit has been studied not only as an outcome but also as a driver of the dynamic process of competition in an industry. One possible mechanism takes the form of spillovers from the exiting firms to the remaining incumbents. A study of the US disk drive industry found that while patent citations in the core technology 
declined soon after the patent holders exited the industry, in the long term, the decline was comparable to those of similar firms who did not exit, implying that knowledge diffusion outlasted exits, generating positive externalities in the industry (Hoetker \& Agarwal, 2007). Exits also shape the rate of technology diffusion. A study of the evolution of the UK digital television system found that the introduction of the new technology was fully enabled by the positive effects of network externalities only in the long term, after the exit of the weakest firms, then outbalancing the negative effects due to the expectation of increasing market competition in the short term (Sillanpää \& Laamanen, 2009).

Another research area examines the sources of interindustry variation in exit rates. In particular, some studies focusing on the manufacturing sector, within a single EU country or across EU countries, have paid attention to differences in the exposure to foreign investments (Havrylchyk, 2012) and to foreign competition (Colantone et al., 2015). Findings show that foreign investments into the domestic bank system increase exit rates in industries characterized by more severe information asymmetries (Havrylchyk, 2012). Foreign import influences market exit but in forms that differ depending on the nature of competition and firmspecific characteristics, such as firm size. While the exit of small firms is influenced by competition from other advanced countries, the exit of large firms is affected more significantly by competition from low-cost countries (Colantone et al., 2015). This approach of study also confirms the well-known correlation between entry and exit rates (Havrylchyk, 2012) and the existence of serial correlation and persistence in exit rates (Cainelli et al., 2014). When industry variation is combined with regional variation, it has been observed that specialization economies, measured by the number of active firms in a certain industry that are co-located in a region, lower exit rates especially for low-tech firms. Hence, the productivity benefits of spatial agglomeration outbalance the stronger pressure from competition in the local market (Cainelli et al., 2014).

A core question in management studies is how the strategic decision to exit a product market by divesting one or more business units can help large established firms to maintain a competitive advantage in the long term. From an evolutionary perspective, the exit from a product market can be seen as the outcome of a process of internal selection by which multi-business firms reallocate resources from the exited business to other business units within the organization. As illustrated in a longitudinal case study documenting the strategic process and sequence of plant closures that led Intel to exit the core DRAM business, this process of internal selection enables companies to replace old competencies and product market strategies with new ones (Burgelman, 1996). The recipient business units are not necessarily existing units but can be newly added to achieve related or unrelated diversification. In the case of related diversification, the process of internal selection through the entry and exit of business units enables the diversifying firm to exploit dynamic economies of scope by redeploying resources from the exited business units to the newly-added (Helfat \& Eisenhardt, 2004). In this perspective, business exit represents a strategic choice aimed at initiating structural change in the parent firm, through the restructuring or refocusing of resources (Decker \& Mellewigt, 2012). As illustrated in the only case study of our review (Salvato et al., 2010), business divestiture was instrumental for the Falck group to pursue novel entrepreneurial opportunities, and to ensure the longevity and success of the established family firm. There can be, however, a delay between the time a firm recognizes the need or opportunity for a market exit and the actual time of business exit when the divestiture of business units takes place. This time lag will vary according to idiosyncratic inertial forces. For example, it has been shown that in family firms a collective culture and a community-controlled structure may slow down the timing of strategic business divestments (Sharma \& Manikutty, 2005).

Market exit can involve either the dissolution or the sell-off of plants and business units (Clark \& Wrigley, 1997). The choice of the mode of exit is influenced by the mode of entry of the business unit, and by the resource fit between the parent firm and the exiting business unit. Because internally developed business units tend to possess firm-specific resources and capabilities, they are more likely to be dissolved than sold off, in comparison to acquired business units, whose resources and capabilities may preserve more value in the market and attract external buyers. Similarly, the resource fit between the parent and the business unit, sharing common resource bases, increases the probability of dissolving rather than selling the unit (Chang \& Singh, 1999). In family firms, identity considerations are likely to motivate the choice of shutting down a satellite business as a preferred option to selling the business to others (Akhter et al., 2016). 


\subsection{Exit from a foreign market}

Studies addressing exit from an internationalization perspective have explored the antecedents of exit from foreign markets seeking to identify the factors that (beyond poor performance) would affect the decision to exit. Attention has been paid to contextual variables, such as various forms of distance between the home and the host country, and firm-specific capabilities, all assumed to shape the relationship between exit and performance.

Exit from a foreign market can be defined with respect to two types of events: the exit of an affiliate firm from a foreign market or the exit from an export market. With regard to the former, studies found that the decision to close a foreign affiliate was more likely if the foreign affiliate, in addition to a poor international performance, lacked international experience (Sousa \& Tan, 2015; Tan \& Sousa, 2019) and strategic fit with the headquarters (Sousa \& Tan, 2015). Furthermore, the probability to exit from a foreign market in response to poor performance was accentuated by cultural distance (Sousa \& Tan, 2015) and by capabilities in radical innovation (Tan \& Sousa, 2019); conversely, the probability of foreign exit was weakened by capabilities in incremental innovation (Tan $\&$ Sousa, 2019), suggesting that situations of greater uncertainty increase the likelihood to exit for underperforming foreign affiliates. Overall, exit rates are higher for foreign affiliates than for domestic firms, because of the liabilities of foreignness due to the additional costs of foreign firms in the host economies. The difference accentuates with firm age, as domestic firms tend to exit earlier than foreign affiliates (Mata \& Freitas, 2012). In fact, age tends to increase rather than decrease the probability of exit of foreign firms: with time, they grow "footloose" because of less attachment to particular local markets than purely domestic firms. In contrast, human capital endowments lower exit probability from foreign markets (Mata $\&$ Portugal, 2000). The notion of "footloose" multinational firms is consistent with the observation that the likelihood of exit of foreign subsidiaries is less affected by domestic market conditions in the host country than domestic firms (Coucke \& Sleuwaegen, 2008).

Macro-economic conditions also affect the liability of foreignness. Varum et al. (2014) observe that while the economic downtown of 1991-1994 in Portugal exacerbated the exit rates of foreign firms in comparison to domestic firms, the difference was not significant in the 2001-2003 downturn, suggesting that domestic firms were in relative terms more penalized than foreign firms in this second crisis, hence providing only partial support to the liability of foreignness argument. Globalization also affects market exit. A study of exit behavior of multinational firms from the Belgian market shows that growing imports from low-wage countries and growing market penetration by multinational firms increase exit in the host country, more substantially for domestic firms than for subsidiaries of multinational firms (Coucke \& Sleuwaegen, 2008). Similarly, by comparing exit rates in eight European countries, Colantone and Sleuwaegen (2010) find that trade openness driven by the import channel increases exit rates, while export intensity does not have a significant effect.

The exit of a foreign firm occurs in different modes: by closing activities or divesting the foreign capital participation. While for both exit modes the exit probability is negatively related to a firm's human capital, it responds differently to other firm-specific characteristics such as ownership structure and mode of entry. Specifically, unlimited liability firms and greenfield foreign entrants are more likely to shut down, while limited liability firms and foreign entrants by acquisition are more likely to be divested or sold off (Mata \& Portugal, 2000).

With regard to exit as withdrawal from exporting to a foreign market, the exit decision is driven by poor export performance by the firm, on various measures: export sales, export growth, total profits (Chen et al., 2019), and productivity (Bernini et al., 2016). Having controlled for performance differences, the relative importance of the specific foreign market in the total assets of the internationalized firm influences the decision to exit, which is more likely to take place in marginal export markets (Chen et al., 2019). Firm-specific resources matter as well. Larger firms (Bernini et al., 2016; Chen et al., 2019), more capital-intensive firms (Bernini et al., 2016), and more internationalized firms (Chen et al., 2019) are less likely to exit export markets. In contrast, firms with longer operating experience are more likely to exit, suggesting that as firms develop capabilities and knowledge they are in a better position and more willing to strategically exit a foreign market (Chen et al., 2019). Similarly, the probability of export exit increases if firms have market-specific import experience prior to entering the export market (Choquette, 2019). This finding is indicative of the dominance of a sunk-costs logic in export exit decision making, in contrast to a learning logic, which would imply instead the 
probability of export exit to decrease with pre-entry import experience. According to a sunk-costs logic, import experience equips firms with market-specific knowledge, lowering barriers to entry and enabling export experimentation for a larger set of firms, including those with lesser export capabilities. As a result, prior experience increases exit rates. This effect is stronger when the cultural distance from the destination market is low (Choquette, 2019).

In addition to individual firm characteristics, the decision to exit export markets has been related to external market conditions. In particular, the likelihood to discontinue exporting increases with the growth rate in the domestic market, as firms can find more profitable opportunities in their home market and shift sales back from exports. Conversely, a significant relationship is found with the growth rate in neighboring foreign markets only for certain types of firms. Namely, smaller and less productive firms are more likely to exit export markets in response to changing conditions in both domestic and foreign markets (Bernini et al., 2016). Firms can alter their export behavior in response to an external shock such as a financial crisis, which undermines access to credit. A study of export behavior in Peruvian firms during the 2008 financial crisis does not find, however, evidence of a significant impact of bank credit shocks on the probability of a firm to enter or exit an export market, with the overall contribution of entries and exits to the total export flow remaining fairly marginal (Paravisini et al., 2014).

Exit from export markets can be followed by re-entry leading to an intermittent pattern of exporting. Export exit and re-entry are inversely correlated: conditions motivating an export exit are also those discouraging the firm to re-enter (Bernini et al., 2016; Chen et al., 2019). Furthermore, the benefits for re-entry from prior experience in export markets fade away over time. In fact, not only the probability to re-enter exporting declines with the time period since a firm's export exit (Bernini et al., 2016) but also the negative correlation between export exit probability and re-entry probability is moderated (strengthened) by the length of time-out from exporting, indicating that the dissipation of the benefits from prior experience for re-entry intensifies, the longer is the time-out from exporting (Chen et al., 2019). Interestingly, a stronger dissipation effect emerges in the less likely event that exit occurs when export performance is high. A possible interpretation is that exit decisions taken when a firm's export performance is favorable are likely to be driven by external "critical incidents," which are disruptive enough to discourage later re-entry (Chen et al., 2019).

It is worth noting that while some studies in this research stream consider the decision to discontinue exporting altogether, shifting a firm's "exporting status" even if temporarily (Bernini et al., 2016), other studies focus on the decision to exit from a particular export market, implying a partial de-internationalization of the firm, which can occur at different rates in different markets (Chen et al., 2019; Choquette, 2019; Paravisini et al., 2014).

\subsection{Exit and market dynamics}

Another strand of literature focuses on exit and market dynamics. The disciplinary perspective of these papers is Economics, rather than Entrepreneurship or Management. Various areas are represented, with some popular themes emerging. First, many recent papers focus on topics of exit and international trade (Feenstra, 2010; Gopinath \& Neiman, 2014; Arkolakis, 2016; Schröder \& Sørensen, 2012; Atkeson \& Burstein, 2010; Egger et al., 2012), or low-wage import competition (Egger et al., 2012; Auer et al., 2013), or on interactions between foreign firms and local firms (Wu et al., 2019). Second, another common theme is exit and the business cycle (Devereux et al., 1993; Pavlov \& Weder, 2012; Cheremukhin \& Tutino, 2016). Third, some contributions investigate how exit relates to the minimum wage (Bhaskar \& To, 1999; Walsh, 2003; Egger et al., 2012).

Many exit papers in this literature stream are purely theoretical papers (e.g., Fattal-Jaef, 2018; Hatfield \& Kominers, 2013; Jovanovic \& Tse, 2010; Chen et al., 2010; Atkeson \& Burstein, 2010; Asturias et al., 2016; Brito \& Dixon, 2013; Atkeson et al., 2015; Garella \& Richelle, 1999; Bhaskar \& To, 1999; Walsh, 2003; Murto, 2004; Bergoeing et al., 2004; Esteve-Perez, 2005; Devereux et al., 1993; Lu, 1994; Clark \& Wrigley, 1997), including theoretical simulation models (Waschik, 2015); and some are a mix of theory and empirics (Peyrache, 2013; Beneito et al., 2017). Formal theoretical modeling appears in many of these papers, in the form of general equilibrium (GE) models (e.g., Bergoeing et al., 2004; Poschke, 2009; Brito \& Dixon, 2009; Feenstra, 2010; Pavlov \& Weder, 2012; PlehnDujowich, 2009; Egger et al., 2012; Boháček \& Zubrický, 2012; Waschik, 2015; Arkolakis, 2016), where exit is the outcome of a competitive selection 
process (e.g., Poschke, 2009; Brito \& Dixon, 2009). This is especially true for some of the earlier economics papers, before the recent "empirical turn" of economics journals towards publishing more empirical papers. Traù (1997) argues for the need of less theoretical and more empirical research. This may mark the end of an era, because these days there are many empirical papers and fewer purely theoretical models. ${ }^{4}$

For the empirical papers in this category, the unit of analysis is often the industry (Boustanifar, 2014; Beneito et al., 2017), or the evolution of the aggregate sector or aggregate economy for different years, and exit is a phenomenon that affects the industry dynamics. Some papers focus on the dynamics of a single industry (e.g., Afuah and Utterback (1991) on the global supercomputer industry) or sector (e.g., Traù (1997) and Doi (1999) on the SME sector), whereas others focus on a comparison of multiple industries (Troske, 1996) or at the level of a national economy (e.g., Carree et al., 2002). Several papers focus on exit specifically in the context of declining industries (Murto, 2004; Esteve-Perez, 2005). Most papers focus on industrialized countries, whereas some focus on emerging economies (Cimoli \& Katz, 2003), and others focus on developing countries from a development economics perspective (Bergoeing et al., 2004; Collier \& Goderis, 2009). The empirical papers are mostly quantitative, although some rather qualitative empirical papers also exist (Cimoli \& Katz, 2003; Webber et al., 1992).

Many of the papers in this strand of literature focus on the dynamic evolutionary themes of Schumpeterian creative destruction (Fok et al., 2019; Carree et al., 2002; Vega-Redondo, 1996), or Darwinian selection (Van Ewijk, 1997; Arkolakis, 2016). Several papers base themselves on the theory of Nelson and Winter's (1982) Evolutionary Theory of Economic Change (Webber et al., 1992; Luo, 2009). Other papers draw upon institutional theory (Gaba \& Terlaak, 2013) and organizational ecology (Gaba \& Terlaak, 2013). Petrakis et al. (1997) focus on the theory of learning curves and industry shakeout. A common theme, therefore, is that the exit of firms is a part

\footnotetext{
${ }^{4}$ Interestingly, Traù, 1997 is a rather 'primordial' empirical paper in the sense that the paper has no data description section or variables description section, and even the definition of exit is not clear.
}

of the natural cycle of reallocation, as the economy advances. The overall outcome would be economic growth or aggregate productivity growth (Sengupta, 2004; Fattal-Jaef, 2018), for example through learning-by-doing (Traù, 1997), or adoption of superior technologies (Webber et al., 1992; Vega Redondo, 1996), or reductions in inefficiency (Peyrache, 2013), or the diffusion of environmentally cleaner technologies (Biorn et al., 1998), or phasing out harmful technologies such as CFC production (Albach et al., 1998). Luo (2009) focuses on how entry and exit affect industry structure (e.g., if the industry converges towards monopolistic competition).

Some of the papers in this stream of literature take exit rates as the explanandum (e.g., Doi, 1999). The vast majority of these papers, however, take exit as a component of economic growth and industrial dynamics in general. In this context, we suggest that a useful framework for considering the role of exit in productivity growth comes from Foster et al. (2001, p. 315) who decompose productivity growth into 5 terms corresponding to (in order of appearance in the equation below) the contribution of learning within continuing (C) plants, the contribution of reallocation between plants, a covariance term, and the contribution of entering (N) plants and exiting (X) plants respectively.

$$
\begin{aligned}
\Delta P_{i t}= & \sum_{e \in C} s_{e t-1} \Delta p_{e t}+\sum_{e \in C}\left(p_{e t-1}-P_{i t-1}\right) \Delta s_{e t-1} \\
& +\sum_{e \in C} \Delta p_{e t} \Delta s_{e t} \\
& +\sum_{e \in N} s_{e t}\left(p_{e t}-P_{i t-1}\right)-\sum_{e \in X} s_{e t-1}\left(p_{e t-1}-P_{i t-1}\right)
\end{aligned}
$$

where $P_{i t}$ is the index of industry productivity, $p_{e t}$ is an index of plant-level productivity, and $s_{e t}$ is the share of plant $e$ in industry $i$ at time $t$. This framework clarifies how exit affects productivity growth. Exit is just one of the channels through which productivity grows, and for exit to have a beneficial effect, the productivity of exiting firms should be below the productivity level of survivors. Recessions, therefore, can be seen as cleansing events that kill the weak and reallocate market share to better firms (Van Ewijk, 1997). However, severe selection events such as strong recessions that lead to the sudden elimination of many (lower productivity) firms can cause significant losses to knowledge and 
therefore to productivity (Van Ewijk, 1997). ${ }^{5}$ Many papers hold that less productive firms exit (e.g., the literature on international trade and heterogeneous firms, such as Schroder and Sorensen (2012) and Atkeson and Burstein (2010)). The Foster et al. (2001) framework also emphasizes the crucial role of heterogeneity across firms: this is necessary to explain why some firms exit while others enter (Das \& Das, 1997). In the equation above, entrants are required to be more productive on average than exiting firms, if net entry is to make a positive contribution to productivity growth.

The focus on aggregate outcomes (e.g., in Foster et al.'s framework above), and on the dynamics of industries rather than individual firms, means that (for the papers in this section) exit is usually conceptualized as a binary rather than allowing for multiple exit routes. For example, exit is the destiny of firms with negative net present value, according to Das and Das (1997). ${ }^{6}$ These papers take different definitions of exit, though. Doi (1999, p. 336) defines exit by referring to firms that lost membership in trade associations. This binary view on exit is implicit in the productivity growth decomposition equation above. Hence, the conceptualization of exit lacks nuance. Exit is generally seen as a failure, and it is usually the domain of firms with below-average productivity (as in the equation above, see also Atkeson and Burstein (2010) and Schroder and Sorensen (2012)), when considered in the context of a selection model (Poschke, 2009). If, after all, exit is the domain of above-average productivity firms, then productivity would ceteris paribus decrease over time because of net entry, which is hardly plausible.

Some exceptions to the simplistic binary view on survival/exit can be found, however. Jovanovic and Rousseau (2008) distinguish between closures, IPOs, and M\&A as outcomes of the introduction of new technologies. While reallocation usually refers to net entry, here reallocation is presented in terms of mergers. Plehn-Dujowich (2009) and Fok et al. (2019) focus on exit vs relocating to another industry. De Gorter et al. (2008) focus on whether cross-subsidization distorts production and leads to misallocation because of

\footnotetext{
5 Bergoeing et al., (2004, see p. 474) focus on whether slow and costly recoveries are the result of impediments to the natural process of resource reallocation.

${ }^{6}$ Vega-Redondo (1996) writes that exit should not be modeled as 'myopic' or 'instantaneous' but firms' decisions are inter-temporal and may be guided by longer term considerations of 'viability' in the context of switching costs and path-dependency of technology choices.
}

allowing firms to avoid exiting. Esteve-Perez (2005) focuses on how the degree of product differentiation affects the order of exit from declining industries. Also, some firms are multiproduct firms and can pay to adjust their product quality. Hence, there is no simple unidimensional indicator of "fitness"; instead, it is more complicated.

The findings and recommendations from this strand of research are usually from the perspective of the (fictional) economic central planner. For example, Carree et al. (2002) argue that exit should be free of stigma and financial burdens for failed entrepreneurs: "Low barriers to entry and exit of business owners are a necessary condition for the equilibrium seeking mechanisms which are vital in our model of the relation between business ownership and economic development" (Carree et al., 2002, p. 285). Siemer (2019) focuses on how financial constraints can hinder job creation through lower growth and exit. Egger et al. (2012) focus on minimum wages and their implications for open economies linked in trade networks. A number of papers discuss how regulations on exit influence industry dynamics. For example, Carree et al. (2002, p. 271) emphasize that "[a]n important policy implication of our exercises is that low barriers to entry and exit of businesses are necessary conditions for the equilibrium seeking mechanisms that are vital for a sound economic development." Poschke (2009) suggests that firing costs for exiting firms have an influence on productivity growth: Poschke predicts that charging firing costs on exiting firms is akin to an exit tax, and thereby hampers selection and reduces growth by 0.1 percentage points (according to a model calibrated on US data). Other papers (Bergoeing et al., 2004; Collier \& Goderis, 2009) focus on a developing country context and discuss how the survival of unviable firms (who receive state support) can be an obstacle to reallocation and can thereby hinder economic growth. $^{7}$

Another set of papers focus on how firm exit affects the economy and society in general, taking into consideration how exit/death involves the dissolution of ongoing responsibilities. Fries et al. (1997) consider exit and debts, discussing the implications not only for the firm but also for investors and other firms in the sector. This is done by relaxing the assumption of infinite maturity for

\footnotetext{
${ }^{7}$ See also Asturias et al., (2016) for further analysis of policy reforms.
} 
firm's debts. ${ }^{8}$ Serpa and Krishnan (2016) discuss the issue of firms that undertake dangerous operations (e.g., involving toxic materials) that may prefer to exit in order to avoid liability. Their recommendation is that the government should provide life-support subsidies in this particular case. Bigelow et al. (1993) investigate an implication of exit, which is that firms are no longer liable to guarantee the warranties they gave consumers. Hatfield and Kominers (2013) discuss the consequences of exit for other firms in the same supply chain. A common assumption in many of these papers is that exit is not entirely unanticipated. Vega-Redondo (1996) explains that exit should not be modeled as "myopic" or "instantaneous," but instead that firms' decisions may be guided by longer term considerations of "viability" in the context of switching costs, path-dependency of technology choices, and inter-temporal tradeoffs.

\section{Overview of the special issue papers}

Following the call for papers for this special edition closed on January 20, 2019, we received 22 submissions; 18 of them were sent to reviewers. Each paper was reviewed by at least two anonymous reviewers and went to three rounds of review on average. The process was completed in autumn 2020 and led to the selection of six papers that are included in this special issue.

Table 3 summarizes the papers included in this issue.

The papers in this special issue portray the variety of dynamics characterizing different exit routes, highlighting common properties as well as distinctive patterns. Kato, Onishi, Honjo (this issue) find that in Japanese manufacturing and information services sectors, new firms that have greater patent stock are less likely to exit by bankruptcy and more likely to exit by merger, and this pattern is consistent for both patent applications and granted patents. Grazzi, Piccardo, Vergari (this issue) contrast involuntary exit and exit by M\&A in Italian firms across the industrial spectrum, showing that while IP protection lowers exits, the impact differs between IP instruments: patents are more relevant to prevent involuntary

\footnotetext{
${ }^{8}$ Fries et al. (1997) focus on how entry and exit affect the valuation of securities and optimal capital structure. Free entry and exit impose reflecting barriers on the price of the industry's output, affecting the valuation of corporate debt and equity and the optimal capital structure decision.
}

exit, and trademarks to prevent exit by M\&A. Mathisen, Shankar, Widding, Rasmussen (this issue) focuses on exit by sell-off, illustrating in a case-study of nine trade sales of research-based spin-offs in Norway, that the potential for synergies and uncertainty reduction, and the presence of credible alternatives, on both the seller and buyer's side, facilitate a successful exit. The papers in this special issue also bring to light the tension in the exit process between the resources and capabilities influencing the prospect of firm exit, and the situations and motivations of individual stakeholders affecting the decision and time of exit. Using longitudinal data on US firms from the Kauffman Firm Survey, Symeonidou, DeTienne, Chirico (this issue) relate the lower likelihood of exit in family firms to a lower threshold of performance, as revealed by the observation that the owners of family firms are more likely to perceive that the business met or exceeded growth expectations when exiting, compared to the owners of non-family firms. Carreira, Teixeira, Nieto-Carrillo (this issue) find a significant proportion of zombie firms - firms that continue to stay in the market when their performance would justify an exit-in the population of manufacturing and services firms in Portugal, but that a recovery and transition out of the zombie status is possible when initiating a process of restructuring, downsizing, and debt restructuring. Coppens and Knockaert (this issue) point out to the family as external stakeholder of firm exit: in a sample of entrepreneurs requesting help for their distressed ventures to a support agency in Belgium, those with no alternative family income and with dependents in the family household were less likely to persist in running the business 2 years after their call for help. Overall, this group of papers provided a relatively balanced portfolio of articles in terms of the type of research questions related to firm exit and type of study.

We hope that our efforts to review knowledge and to produce a dedicated issue on firm exit will lead to furthering our understanding of the topic. However, there remain many opportunities for scholars to engage more fully with firm exit, especially from an empirical and methodological standpoint.

\section{Conclusions and research agenda}

We reviewed the literature on firm exit and depicted the major thematic areas and established patterns. This review has some limitations. Our query was focused on the concept of "firm exit." While this has allowed us to 
Table 3 The papers included in the special issue on firm exit

\begin{tabular}{|c|c|c|c|c|}
\hline Authors & Research question & Data & Types of exit & Main findings \\
\hline $\begin{array}{l}\text { Masatoshi Kato, } \\
\text { Koichiro } \\
\text { Onishi, and Yuji } \\
\text { Honjo }\end{array}$ & $\begin{array}{l}\text { How the survival chances of } \\
\text { new firms with patent stock } \\
\text { vary across exit routes } \\
\text { (bankruptcy, voluntary } \\
\text { liquidation, and merger)? }\end{array}$ & $\begin{array}{l}5270 \text { new Japanese firms from } \\
2003 \text { to } 2013\end{array}$ & $\begin{array}{l}\text { Firm exit } \\
\text { (bankruptcy, } \\
\text { voluntary } \\
\text { liquidation, } \\
\text { and merger) }\end{array}$ & $\begin{array}{l}\text { Overall, new firms that have } \\
\text { greater patent stock are less } \\
\text { likely to exit by bankruptcy } \\
\text { and more likely to exit by } \\
\text { merger. These results are } \\
\text { consistent for both patent } \\
\text { applications and granted } \\
\text { patents. }\end{array}$ \\
\hline $\begin{array}{l}\text { Noni Symeonidou, } \\
\text { Dawn R. } \\
\text { DeTienne, and } \\
\text { Francesco } \\
\text { Chirico }\end{array}$ & $\begin{array}{l}\text { How performance thresholds } \\
\text { affect exit in family firms? }\end{array}$ & $\begin{array}{l}1191 \text { US firms over the period } \\
\text { 2008-2011 (Kauffman Firm } \\
\text { Survey, KFS) }\end{array}$ & $\begin{array}{l}\text { Firm exit } \\
\text { (focus on } \\
\text { family firms) }\end{array}$ & $\begin{array}{l}\text { As a result of socioemotional } \\
\text { benefits, family firms have } \\
\text { lower thresholds than } \\
\text { non-family firms and are thus } \\
\text { more willing to persist with } \\
\text { their businesses. }\end{array}$ \\
\hline $\begin{array}{l}\text { Carlos Carreira, } \\
\text { Paulino Teixeira } \\
\text { and Ernesto } \\
\text { Nieto-Carrillo }\end{array}$ & $\begin{array}{l}\text { How can zombie firms survive } \\
\text { for long periods? Are they } \\
\text { inherently unviable? And } \\
\text { what are the factors that drive } \\
\text { zombies to recover rather } \\
\text { than exiting? }\end{array}$ & $\begin{array}{l}\text { 273,907 Portuguese } \\
\text { manufacturing and services } \\
\text { firms covering the } \\
\text { 2004-2017 period }\end{array}$ & $\begin{array}{l}\text { Firm exit } \\
\text { (focus on } \\
\text { recovery of } \\
\text { zombie } \\
\text { firms) }\end{array}$ & $\begin{array}{l}\text { Most zombie firms are } \\
\text { "entrenched", that is, with a } \\
\text { higher probability of } \\
\text { non-transition into alternative } \\
\text { states. However, downsizing } \\
\text { and restructuring, as well as } \\
\text { debt restructuring, are crucial } \\
\text { for recovering zombie firms. }\end{array}$ \\
\hline $\begin{array}{l}\text { Marius Tuft } \\
\text { Mathisen, Raj } \\
\text { Krishnan } \\
\text { Shankar, } \\
\text { Øystein } \\
\text { Widding, Einar } \\
\text { Rasmussen }\end{array}$ & $\begin{array}{l}\text { What are the enabling factors of } \\
\text { exit via trade sale of } \\
\text { research-based spin-offs? }\end{array}$ & $\begin{array}{l}9 \text { trade sales of research-based } \\
\text { spin-offs in Norway }\end{array}$ & $\begin{array}{l}\text { Firm exit } \\
\text { (focus on } \\
\text { trade sales) }\end{array}$ & $\begin{array}{l}\text { Three elements determine a } \\
\text { successful trade sale: 1) } \\
\text { potential synergies, 2) } \\
\text { credible alternatives, and 3) } \\
\text { uncertainty reduction. These } \\
\text { are linked to the focal venture } \\
\text { but also related to the } \\
\text { idiosyncratic dyad with the } \\
\text { buyer. }\end{array}$ \\
\hline $\begin{array}{l}\text { Marco Grazzi, } \\
\text { Chiara Piccardo, } \\
\text { Cecilia Vergari }\end{array}$ & $\begin{array}{l}\text { What is the impact of patents } \\
\text { and trademarks, and other } \\
\text { firm characteristics, across } \\
\text { different exit modes } \\
\text { (involuntary and M\&A)? }\end{array}$ & $\begin{array}{l}\text { Around 400,000 Italian firms on } \\
\text { average per year from } \\
\text { manufacturing, trade and } \\
\text { service. Period: } 2005-2014 ; \\
\text { source: Infocamere, AIDA } \\
\text { (Bureau Van Dijk) }\end{array}$ & $\begin{array}{l}\text { Firm exit } \\
\text { (focus on } \\
\text { involuntary } \\
\text { exit and exit } \\
\text { via M\&A) }\end{array}$ & $\begin{array}{l}\text { Intellectual Property } \\
\text { instruments reduce the } \\
\text { probability of involuntary } \\
\text { exit and M\&A. } \\
\text { The relative impact changes } \\
\text { however with the mode of } \\
\text { exit: patents are more relevant } \\
\text { than trademarks in preventing } \\
\text { involuntary exit; the opposite } \\
\text { holds for M\&A. }\end{array}$ \\
\hline $\begin{array}{l}\text { Karlien Coppens, } \\
\text { Mirjam } \\
\text { Knockaert }\end{array}$ & $\begin{array}{l}\text { Under which conditions } \\
\text { entrepreneurs are more or less } \\
\text { likely to persist with their } \\
\text { distressed venture? }\end{array}$ & $\begin{array}{l}231 \text { entrepreneurs in Belgium } \\
\text { who called upon help from a } \\
\text { support agency for distressed } \\
\text { ventures in } 2016\end{array}$ & $\begin{array}{l}\text { Individual and } \\
\text { firm exit } \\
\text { (focus on } \\
\text { entrepre- } \\
\text { neurial } \\
\text { persistence) }\end{array}$ & $\begin{array}{l}\text { Persistence is more evident for } \\
\text { entrepreneurs of firms with } \\
\text { more employees and with } \\
\text { lower levels of operating } \\
\text { debts. When the firm's level } \\
\text { of operating debts increases, } \\
\text { the probability of persistence } \\
\text { decreases for entrepreneurs } \\
\text { with no alternative family } \\
\text { income and with dependent } \\
\text { family members. }\end{array}$ \\
\hline
\end{tabular}


represent the academic debate in all instances where scholars have referred explicitly to this concept, studies on sibling concepts (e.g., firm survival, zombie firms) risk being overlooked. As our review shows, research on firm exit has advanced considerably over the past decades, and the papers included in this special issue witness these developments, further advancing our understanding of the phenomenon. Based on these insights, we can now provide a focused set of suggestions for future research.

The understanding of firm exit has evolved from the view of exit as a homogenous event signaling the termination of business activity due to organizational liabilities and the operating of market selection, to a vision of exit as a heterogenous event. Exploring the sources of heterogeneity of exits from various perspectives could offer promising paths for future research.

Heterogeneity of forms There is now general awareness in empirical research on firm survival, of the multiplicity of exit routes, in contrast to a binary representation, in which exit is implicitly the one's complement of survival (exit as "non-survival"). The most common exit routes in the surveyed literature are bankruptcy, voluntary liquidation, and M\&A, with some awareness of modes of entrepreneurial exit corresponding to IPO and $\mathrm{MBO}$ (management buy-out). Future research could identify further exit routes in a finer-grained analysis of exit, e.g., distinguishing between motivations for voluntary liquidation and positioning them along a spectrum from "failure" to success. Similarly, exit via M\&A could be situated along a continuum ranging from favorable acquisitions paid at a premium, to asset-stripping acquisitions at fire-sale prices.

Heterogeneity of meanings Firm exit has lost its pejorative meaning (exit as "failure") in view of the recognition that exit events are not necessarily commercial failures. Even outright commercial failure is being increasingly emancipated from its earlier stigma, in the eyes of scholars, investors, and policymakers, because it does not do justice to initiatives in the category of "worthwhile bets that were unlucky." On the other hand, there is increasing reluctance to equate survival to success, pointing out that persisting "zombie firms" would do better to exit, while acquisitions are increasingly viewed as favorable outcomes. Market selection processes lack empathy and may hinder experimentation when potentially valuable but fragile firms are selected out too soon. A research question could be whether some exits are type I errors (i.e., exits of fundamentally viable firms), in contradistinction to type II errors (involving the survival of underperforming or zombie firms).

Heterogeneity of motivations Exit is the balanced action of multiple stakeholders, including founders, managers, investors, and potential buyers, with different motivations and attitudes towards exit. Our review of the literature seems to indicate that the differentiation between voluntary and involuntary exit is relatively underresearched. What are the factors that can prolong survival by delaying voluntary exits, or convert a potential voluntary exit into a trade sale or M\&A? Is the type of buyer important herein (e.g., differentiating between individuals, strategic or financial buyers)? While exits are mostly associated with independent ventures, for which personal motivations matter, business exits are the outcome of the strategic process of resource reconfiguration of larger groups. What is the role of exits in the internal selection process of large corporations?

Heterogeneity of contexts The meanings of exit routes vary across institutional contexts. M\&A is procyclical in the USA but countercyclical in Japan, because M\&A corresponds to "rescue mergers" in Japan. Also, voluntary liquidation is common among Japanese SMEs because the legal consequences of bankruptcy are severe and best avoided. Bankruptcy therefore is more common for larger Japanese firms who can pay the large, fixed costs of the legal bankruptcy procedures, with less personal liability for the CEO. What is the role of selection events such as the financial crisis? The business cycle strongly affects exit routes. Merger waves occur during booms, and bankruptcies are probably more common in recessions. But what about voluntary liquidation - is this somehow cyclical? If voluntary liquidation occurs independently of financial pressures (e.g., for retirement or lifestyle reasons), then it could be invariant to the business cycle, whereas if voluntary liquidation is merely a last-ditch attempt to save face and "snatch victory from the jaws of defeat," it could be closely linked to the business cycle.

Methodologies in exit research have advanced in parallel to the development of an increasingly multilayered approach to exit. Competing risk models, designed for databases with multiple exit routes (as opposed to a binary survival variable), are increasingly 
common. Piecewise hazard models have been applied to model the effects of environmental jolts. Survival econometrics could also apply techniques that can better incorporate variables that are time-varying, thus capturing the dynamic nature of exit as a process unfolding over time rather than a sole end result.

Acknowledgements The authors thank all the participants, the keynote speaker, Marco Vivarelli, and the discussants Daniela Andreini, Eleonora Bartoloni, and Silvio Vismara of the Paper Development Workshop (PDW) 'UNDERSTANDING FIRMS' EXIT ROUTES: The role of strategies, approach, timing and context" held at University of Bergamo (May 17-18, 2019). Special thanks go to the Editor-in-chief, David Audretsch, and to all the reviewers that had made possible this Special Issue.

Funding Open access funding provided by Università degli studi di Bergamo within the CRUI-CARE Agreement. Elena Cefis acknowledges financial support from the University of Bergamo (grants ex 60\%, n. 60CEFI17 and n. 60CEFI18). Elena Cefis and Cristina Bettinelli acknowledge the financial support offered by Montello S.p.A and by the Department of Management, Economics, and Quantitative Methods for the realization of the PDW. Alex Coad acknowledges financial support from the National Research Foundation of Korea Grant funded by the Korean Government (NRF-2018S1A3A2075175).

Open Access This article is licensed under a Creative Commons Attribution 4.0 International License, which permits use, sharing, adaptation, distribution and reproduction in any medium or format, as long as you give appropriate credit to the original author(s) and the source, provide a link to the Creative Commons licence, and indicate if changes were made. The images or other third party material in this article are included in the article's Creative Commons licence, unless indicated otherwise in a credit line to the material. If material is not included in the article's Creative Commons licence and your intended use is not permitted by statutory regulation or exceeds the permitted use, you will need to obtain permission directly from the copyright holder. To view a copy of this licence, visit http://creativecommons.org/licenses/by/4.0/.

\section{References}

(with an asterisk indicate papers that were included in our review)

*Afuah, A. N., and Utterback, J. M. (1991). The emergence of a new supercomputer architecture. Technological Forecasting and Social Change, 40(4), 315-328.

*Aga, G., Francis, D. (2017). As the market churns: Productivity and firm exit in developing countries. Small Business Economics, 49(2), 379-403.

*Akhter, N., Sieger, P., Chirico, F. (2016). If we can't have it, then no one should: Shutting down versus selling in family business portfolios. Strategic Entrepreneurship Journal, 10(4), 371-394.

*Albach, H., Krupa, E., Koster, D. (1998). Entry, entry-deterrence and exit: A study of the market for CFCs. Kyklos, 51(4), 469-488.

*Albert, L. S., DeTienne, D. R. (2016). Founding resources and intentional exit sales strategies: An imprinting perspective. Group and Organization Management, 41(6), 823-846.

*Amit, R., Brander, J., Zott, C. (1998). Why do venture capital firms exist? Theory and Canadian evidence. Journal of Business Venturing, 13(6), 441-466.

*Arbia, G., Espa, G., Giuliani, D., Dickson, M. M. (2014). Spatiotemporal clustering in the pharmaceutical and medical device manufacturing industry: A geographical micro-level analysis. Regional Science and Urban Economics, 49, 298-304.

*Armand, A., Mendi, P. (2018). Demand drops and innovation investments: Evidence from the great recession in Spain. Research Policy, 47(7), 1321-1333.

*Arkolakis, C. (2016). A unified theory of firm selection and growth. Quarterly Journal of Economics, 131(1), 89-155.

*Asturias, J., Hur, S., Kehoe, T. J., \& Ruhl, K. J. (2016). The interaction and sequencing of policy reforms. Journal of Economic Dynamics and Control, 72, 45-66.

Atewologun, D., Kutzer, R., Doldor, E., Anderson, D., \& Sealy, R. (2017). Individual-level foci of identification at work: a systematic review of the literature. International Journal of Management Reviews, 19(3), 273-295.

*Atkeson, A., and Burstein, A. T. (2010). Innovation, firm dynamics, and international trade. Journal of Political Economy, 118(3), 433-484.

*Atkeson, A., Hellwig, C., Ordoñez, G. (2015). Optimal regulation in the presence of reputation concerns. Quarterly Journal of Economics, 130(1), 415-464.

Audretsch, D. B. (1995). Innovation, growth and survival. International Journal of Industrial Organization, 13, 441457.

Audretsch, D. B., \& Mahmood, T. (1994). The rate of hazard confronting new firms and plants in U.S. manufacturing. Review of Industrial Organization, 9, 41-56.

*Auer, R. A., Degen, K., Fischer, A. M. (2013). Low-wage import competition, inflationary pressure, and industry dynamics in Europe. European Economic Review, 59, 141-166.

Balcaen, S., Manigart, S., \& Ooghe, H. (2011). From distress to exit: Determinants of the time to exit. Journal of Evolutionary Economics, 21(3), 407-446.

*Balcaen, S., Manigart, S., Buyze, J., Ooghe, H. (2012). Firm exit after distress: Differentiating between bankruptcy, voluntary liquidation and M\&a. Small Business Economics, 39(4), 949-975.

Baldwin, J.R. (Ed.). (1995). The Dynamics of Industrial Competition: A North American Perspective. Cambridge University Press, Cambridge.

Baldwin, J. R., \& Gorecki, P. K. (1991). Firm entry and exit in the Canadian manufacturing sector, 1970-1982. Canadian Journal of Economics, 24, 300-323.

Bartik, A. W., Bertrand, M., Cullen, Z. B., Glaeser, E. L., Luca, M., Stanton, C. T. (2020). How are small businesses adjusting to covid-19? Early evidence from a survey (no. w26989). National Bureau of Economic Research. 
*Basile, R., Pittiglio, R., Reganati, F. (2017). Do agglomeration externalities affect firm survival? Regional Studies, 51(4), $548-562$.

Baum, J. A. C. (1996). Organizational ecology. In S. Clegg, C. Hardy, \& W. Nord (Eds.), Handbook of organization studies. London: Sage.

*Beaudin, L., and Huang, J.-C. 2014. Weather conditions and outdoor recreation: A study of New England ski areas. Ecological Economics, 106: 56-68.

*Benabou, R. (1992). Inflation and efficiency in search markets. Review of Economic Studies, 59(2), 299-329.

*Beneito, P., Rochina-Barrachina, M. E., \& Sanchis, A. (2017). Competition and innovation with selective exit: An invertedU shape relationship? Oxford Economic Papers, 69(4), 1032-1053.

*Bennett, V. M., Hall, T. A. (2020). Software availability and entry. Strategic Management Journal, 41(5), 950-962.

*Bennmarker, H., Mellander, E., Öckert, B. (2009). Do regional payroll tax reductions boost employment? Labour Economics, 16(5), 480-489.

*Bergoeing, R., Loayza, N., Repetto, A. (2004). Slow recoveries. Journal of Development Economics, 75(2), 473-506.

*Bernard, A. B., Smeets, V., Warzynski, F. (2017). Rethinking deindustrialization. Economic Policy, 32(89), 5-38.

*Bernini, M., Du, J., Love, J. H. 2016. Explaining intermittent exporting: Exit and conditional re-entry in export markets. Journal of International Business Studies, 47(9): 1058-1076.

*Bhaskar, V., and To, T. (1999). Minimum wages for Ronald McDonald monopsonies: A theory of monopsonistic competition. Economic Journal, 109(455), 190-203.

*Bhattacharjee, A., Higson, C., Holly, S., Kattuman, P. (2009). Macroeconomic instability and business exit: Determinants of failures and acquisitions of UK firms. Economica, 76(301), 108-131.

*Bigelow, J., Cooper, R., Ross, T. W. (1993). Warranties without commitment to market participation. International Economic Review, 85-100.

*Biørn, E., Golombek, R., Raknerud, A. (1998). Environmental regulations and plant exit. Environmental and Resource Economics, 11(1), 35-59.

*Boháček, R., \& Zubrický, J. (2012). A flat tax reform in an economy with occupational choice and financial frictions. Economic Journal, 122(565), 1313-1345.

*Bosma, N., Stam, E., Schutjens, V. (2011). Creative destruction and regional productivity growth: Evidence from the Dutch manufacturing and services industries. Small Business Economics, 36(4), 401-418.

*Boustanifar, H. (2014). Finance and employment: Evidence from US banking reforms. Journal of Banking and Finance, 46, 343-354.

Bradley, S. W., Aldrich, H., Shepherd, D. A., \& Wiklund, J. (2011). Resources, environmental change, and survival: Asymmetric paths of young independent and subsidiary organizations. Strategic Management Journal, 32(5), 486-509.

*Brito, P., and Dixon, H. (2009). Entry and the accumulation of capital: A two state variable extension to the Ramsey model. International Journal of Economic Theory, 5(4), 333-357.

*Brito, P., and Dixon, H. (2013). Fiscal policy, entry and capital accumulation: Hump-shaped responses. Journal of Economic Dynamics and Control, 37(10), 2123-2155.
Bruderl, J., Preisendorfen, P., \& Ziegler, R. (1992). Survival chances of newly founded business organizations. American Sociological Review, 57, 227-242.

*Bruyaka, O., Durand, R. (2012). Sell-off or shut-down? Alliance portfolio diversity and two types of high-tech firms' exit. Strategic Organization, 10(1), 7-30.

Burgelman, R. A. (1994). Fading memories: A process theory of strategic business exit in dynamic environments. Administrative Science Quarterly, 24-56.

*Burgelman, R. A. (1996). A process model of strategic business exit: Implications for an evolutionary perspective on strategy. Strategic Management Journal, 17(S1), 193-214.

*Buzzelli, M. 2005. What explains firm transience in house-building? A regional analysis of Ontario, Canada, 1991 and 1996. Regional Studies, 39(6): 699-712.

*Cainelli, G., Montresor, S., Marzetti, G. V. 2014. Spatial agglomeration and firm exit: A spatial dynamic analysis for Italian provinces. Small Business Economics, 43(1): 213228.

*Camacho, A., Rodriguez, C. (2013). Firm exit and armed conflict in Colombia. Journal of Conflict Resolution, 57(1), 89-116.

*Capasso, M., Treibich, T., Verspagen, B. (2015). The mediumterm effect of R\&D on firm growth. Small Business Economics, 45(1), 39-62.

*Carree, M., Van Stel, A., Thurik, R., Wennekers, S. (2002). Economic development and business ownership: An analysis using data of 23 OECD countries in the period 1976-1996. Small Business Economics, 19(3), 271-290.

*Carreira, C., Teixeira, P. (2016). Entry and exit in severe recessions: Lessons from the 2008-2013 Portuguese economic crisis. Small Business Economics, 46(4), 591-617.

Caves, R. E. (1998). Industrial organization and new findings on the turnover and mobility of firms. Journal of Economic Literature, 36, 1947-1982.

*Cefis, E., Marsili, O. (2012). Going, going, gone. Exit forms and the innovative capabilities of firms. Research Policy, 41(5), 795-807.

Cefis, E., and Marsili, O. (2019), Good Times, Bad Times: Innovation and Survival over the Business Cycle, forthcoming in Industrial and Corporate Change.

*Cefis, E., Marsili, O. (2006). Survivor: The role of innovation in firms' survival. Research Policy, 35(5), 626-641.

Cefis, E., \& Marsili, O. (2005). A matter of life and death: Innovation and firm survival. Industrial and Corporate Change, 14(6), 1167-1192.

*Cerqueiro, G., Penas, M. F., Seamans, R. (2019). Debtor protection and business dynamism. The Journal of Law and Economics, 62(3), 521-549.

Chang, S. J. (1996). An evolutionary perspective on diversification and corporate restructuring: Entry, exit, and economic performance during 1981-89. Strategic Management Journal, 587-611.

*Chang, S. J., and Singh, H. (1999). The impact of modes of entry and resource fit on modes of exit by multibusiness firms. Strategic Management Journal, 20(11), 1019-1035.

*Chemmanur, T. J., He, J., He, S., Nandy, D. K. (2018). Product market characteristics and the choice between IPOs and acquisitions. Journal of Financial and Quantitative Analysis 53(2), 681-721. 
*Chen, H., Miao, J., \& Wang, N. (2010). Entrepreneurial finance and nondiversifiable risk. Review of Financial Studies, 23(12), 4348-4388.

*Chen, J., Sousa, C. M. P., He, X. (2019). Export market re-entry: Time-out period and price/quality dynamisms. Journal of World Business, 54(2): 154-168.

*Cheremukhin, A., \& Tutino, A. (2016). Information rigidities and asymmetric business cycles. Journal of Economic Dynamics and Control, 73, 142-158.

Chirico, F., Gómez-Mejia, L. R., Hellerstedt, K., Withers, M., \& Nordqvist, M. (2020). To merge, sell, or liquidate? Socioemotional wealth, family control, and the choice of business exit. Journal of Management, 46(8), 1342-1379.

*Cho, I., and Orazem, P. F. (2020). How endogenous risk preferences and sample selection affect analysis of firm survival. Small Business Economics: 1-24.

*Choquette, E. 2019. Import-based market experience and firms' exit from export markets. Journal of International Business Studies, 50(3): 423-449.

*Cimoli, M., and Katz, J. (2003). Structural reforms, technological gaps and economic development: A Latin American perspective. Industrial and Corporate Change, 12(2), 387-411.

*Clark, G. L., Wrigley, N. (1997). Exit, the firm and sunk costs: Reconceptualizing the corporate geography of disinvestment and plant closure. Progress in Human Geography, 21(3), 338-358.

*Coad, A. (2014). Death is not a success: Reflections on business exit. International Small Business Journal, 32(7), 721-732.

Coad, A., \& Guenther, C. (2013). Diversification patterns and survival as firms mature. Small Business Economics, 41(3), 633-649.

Coad, A., Frankish, J. S., Roberts, R. G., \& Storey, D. J. (2013). Growth paths and survival chances: An application of Gambler's ruin theory. Journal of Business Venturing, 28, 615-632.

*Colantone, I., Coucke, K., \& Sleuwaegen, L. (2015). Low-cost import competition and firm exit: evidence from the EU. Industrial and Corporate Change, 24(1), 131-161.

*Colantone, I., Sleuwaegen, L. (2010). International trade, exit and entry: A cross-country and industry analysis. Journal of International Business Studies, 41(7), 1240-1257.

*Collier, P., and Goderis, B. (2009). Structural policies for shockprone developing countries. Oxford Economic Papers, 61(4), 703-726.

*Cotei, C., Farhat, J. (2018). The M\&A exit outcomes of new, young firms. Small Business Economics, 50(3), 545-567.

*Coucke, K., Sleuwaegen, L. (2008). Offshoring as a survival strategy: Evidence from manufacturing firms in Belgium. Journal of International Business Studies, 39(8), 1261-1277.

*Das, S., and Das, S. P. (1997). Dynamics of entry and exit of firms in the presence of entry adjustment costs. International Journal of Industrial Organization, 15(2), 217-241.

*Dawley, D. D., Hoffman, J. J., Lamont, B. T. (2002). Choice situation, refocusing, and post-bankruptcy performance. Journal of Management, 28(5), 695-717.

*Decker, C., Mellewigt, T. (2007). Thirty years after Michael E. Porter: What do we know about business exit? Academy of Management Perspectives, 21(2), 41-55.

*Decker, C., Mellewigt, T. (2012). Business exit and strategic change: Sticking to the knitting or striking a new path? British Journal of Management, 23(2), 165-178. de Figueiredo, J. M., \& Silverman, B. S. (2007). Churn, baby, churn: Strategic dynamics among dominant and fringe firms in a segmented industry. Management Science, 53(4), 632 650.

de Figueiredo, J. M., \& Silverman, B. S. (2012). Firm survival and industry evolution in vertically related populations. Management Science, 58(9), 1632-1650.

*De Gorter, H., Just, D. R., \& Kropp, J. D. (2008). Crosssubsidization due to inframarginal support in agriculture: A general theory and empirical evidence. American Journal of Agricultural Economics, 90(1), 42-54.

*Devereux, M. B., Head, A. C., \& Lapham, B. J. (1993). Monopolistic competition, technology shocks, and aggregate fluctuations. Economics Letters, 41(1), 57-61.

DeTienne, D. R. (2010). Entrepreneurial exit as a critical component of the entrepreneurial process: Theoretical development. Journal of Business Venturing, 25, 203-215.

DeTienne, D. R., \& Wennberg, K. (2015). Research handbook of entrepreneurial exit. Edward Elgar Publishing.

*Dimara, E., Skuras, D., Tsekouras, K., Tzelepis, D. (2008). Productive efficiency and firm exit in the food sector. Food Policy, 33(2), 185-196.

*Dixit, A., and Chintagunta, P. K. 2007. Learning and exit behavior of new entrant discount airlines from city-pair markets. Journal of Marketing, 71(2): 150-168.

*Doi, N. (1999). The determinants of firm exit in Japanese manufacturing industries. Small Business Economics, 13(4), 331-337.

Dunne, T., Roberts, M. J., \& Samuelson, L. (1988). Patterns of firm entry and exit in the U.S. manufacturing industries. RAND Journal of Economics, 19, 495-515.

Ebert, T., Brenner, T., \& Brixy, U. (2018). New firm survival: The interdependence between regional externalities and innovativeness. Small Business Economics.

*Egger, H., Egger, P., Markusen, J. R. (2012). International welfare and employment linkages arising from minimum wages. International Economic Review, 53(3), 771-790.

*Esteve-Pérez, S. (2005). Exit with vertical product differentiation. International Journal of Industrial Organization, 23(34), 227-247.

Evans, D. S. (1987). The relationship between firm growth, size, and age: Estimates for 100 manufacturing industries. Journal of Industrial Economics, 35, 567-581.

*Fafchamps, M., Schündeln, M. (2013). Local financial development and firm performance: Evidence from Morocco. Journal of Development Economics, 103, 15-28.

*Fattal-Jaef, R.N. (2018). "Entry and exit, multiproduct firms, and allocative distortions." American Economic Journal: Macroeconomics, 10(2), 86-112.

*Feenstra, R. C. (2010). Measuring the gains from trade under monopolistic competition. Canadian Journal of Economics/ Revue canadienne d'économique, 43(1), 1-28.

*Fok, D., van Stel, A., Burke, A., Thurik, R. (2019). How entry crowds and grows markets: The gradual disaster management view of market dynamics in the retail industry. Annals of Operations Research, 283(1-2), 1111-1138.

*Fortune, A., Mitchell, W. (2012). Unpacking firm exit at the firm and industry levels: The adaptation and selection of firm capabilities. Strategic Management Journal, 33(7), 794-819.

Foster L., Haltiwanger J.C., Krizan C.J. (2001). Aggregate productivity growth. Lessons from microeconomic evidence. 
Chapter 8, pages 303-372 in: New Developments in Productivity Analysis. Edited by Charles R. Hulten, Edwin R. dean and Michael J. Harper. University of Chicago Press. http://www.nber.org/chapters/c10129

*Fraisse, H., Hombert, J., Lé, M. (2018). The competitive effect of a bank megamerger on credit supply. Journal of Banking and Finance, 93, 151-161.

*Frazer, G. (2005). Which firms die? A look at manufacturing firm exit in Ghana. Economic Development and Cultural Change, 53(3), 585-617.

Freeman, J., Carroll, G. R., \& Hannan, M. T. (1983). The liability of newness: Age dependence in organizational death rates. American Sociological Review, 48, 692-710.

*Fries, S., Miller, M., Perraudin, W. (1997). Debt in industry equilibrium. Review of Financial Studies, 10(1), 39-67.

*Furr, N., Kapoor, R. (2018). Capabilities, technologies, and firm exit during industry shakeout: Evidence from the global solar photovoltaic industry. Strategic Management Journal, 39(1), 33-61.

*Gaba, V., Terlaak, A. (2013). Decomposing uncertainty and its effects on imitation in firm exit decisions. Organization Science, 24(6), 1847-1869.

*Garella, P. G., and Richelle, Y. (1999). Exit, sunk costs and the selection of firms. Economic Theory, 13(3), 643-670.

Geroski, P. A. (1995). What do we know about entry? International Journal of Industrial Organization, 13, 421440.

*Goktan, M. S., Kieschnick, R., Moussawi, R. (2018). Corporate governance and firm survival. Financial Review, 53(2), 209253.

*Golombek, R., Raknerud, A. (2018). Exit dynamics of start-up firms: Structural estimation using indirect inference. Journal of Econometrics, 205(1), 204-225.

*Gopinath, G., and Neiman, B. (2014). Trade adjustment and productivity in large crises. American Economic Review, 104(3), 793-831.

Graebner, M. E., \& Eisenhardt, K. M. (2004). The seller's side of the story: Acquisition as courtship and governance as syndicate in entrepreneurial firms. Administrative Science Quarterly, 49(3), 366-403.

*Gras, D., Mendoza-Abarca, K. I. (2014). Risky business? The survival implications of exploiting commercial opportunities by nonprofits. Journal of Business Venturing, 29(3), 392404.

Greenhalgh, T. (1997). How to read a paper: Papers that summarise other papers (systematic reviews and meta-analyses). British Medical Journal, 315, 672-675.

Guerrieri, V., Lorenzoni, G., Straub, L., Werning, I. (2020). Macroeconomic implications of COVID-19: Can negative supply shocks cause demand shortages? (no. w26918). National Bureau of Economic Research.

Hall, B. H. (1987). The relationship between firm size and firm growth in the US manufacturing sector. Journal of Industrial Economics, 35, 583-606.

*Hansen, M. E., Ziebarth, N. L. (2017). Credit relationships and business bankruptcy during the great depression. American Economic Journal: Macroeconomics, 9(2), 228-255.

*Harada, N. 2007. Which firms exit and why? An analysis of small firm exits in Japan. Small Business Economics, 29(4): 401-414.
*Hatfield, J. W., and Kominers, S. D. (2013). Vacancies in supply chain networks. Economics Letters, 119(3), 354-357.

*Havrylchyk, O. 2012. The effect of foreign bank presence on firm entry and exit in transition economies. Journal of Banking and Finance, 36(6): 1710-1721.

*Heijdra, B. J., and Ploeg, F. V. D. (1996). Keynesian multipliers and the cost of public funds under monopolistic competition. Economic Journal, 106(438), 1284-1296.

*Helfat, C. E., and Eisenhardt, K. M. (2004). Inter-temporal economies of scope, organizational modularity, and the dynamics of diversification. Strategic Management Journal, 25(13), 1217-1232.

*Higgins, D., Toms, S., Filatotchev, I. (2015). Ownership, financial strategy and performance: The Lancashire cotton textile industry, 1918-1938. Business History, 57(1), 97-121.

*Hoetker, G., and Agarwal, R. 2007. Death hurts, but it Isn't fatal: The Postexit diffusion of knowledge created by innovative companies. Academy of Management Journal, 50(2): 446467.

*Hsu, D. K., Wiklund, J., Cotton, R. D. 2017. Success, failure, and entrepreneurial reentry: An experimental assessment of the veracity of self-efficacy and Prospect theory. Entrepreneurship Theory and Practice, 41(1): 19-47.

*Jensen, R., Miller, N. H. (2018). Market integration, demand, and the growth of firms: Evidence from a natural experiment in India. American Economic Review, 108(12), 3583-3625.

*Johansson, D. (2005). The turnover of firms and industry growth. Small Business Economics, 24(5), 487-495.

Josefy, M. A., Harrison, J. S., Sirmon, D. G., \& Carnes, C. (2017). Living and dying: Synthesizing the literature on firm survival and failure across stages of development. Academy of Management Annals, 11(2), 770-799.

*Jovanovic, B., and Tse, C. Y. (2010). Entry and exit echoes. Review of Economic Dynamics, 13(3), 514-536.

*Jovanovic, B., and Rousseau, P. L. (2008). Mergers as reallocation. Review of Economics and Statistics, 90(4), 765-776.

*Kalafsky, R. V., and MacPherson, A. D. 2006. The post-1990 rebirth of the US machine tool industry: A temporary recovery? Technovation, 26(5-6): 665-671.

*Kim, Y. J., Tesar, L. L., Zhang, J. (2015). The impact of foreign liabilities on small firms: Firm-level evidence from the Korean crisis. Journal of International Economics, 97(2), 209-230.

*Klapper, L., Richmond, C. (2011). Patterns of business creation, survival and growth: Evidence from Africa. The World Bank.

*Kumar, P., Zhang, H. (2019). Productivity or unexpected demand shocks: What determines firms' investment and exit decisions? International Economic Review, 60(1), 303-327.

Leroy, H., Manigart, S., Meuleman, M., \& Collewaert, V. (2015). Understanding the continuation of firm activities when entrepreneurs exit their firms: Using theory of planned behaviour. Journal of Small Business Management, 53(2), 400 415.

*Lööf, H., Heshmati, A. (2002). Knowledge capital and performance heterogeneity: A firm-level innovation study. International Journal of Production Economics, 76(1), 6185.

*Lu, D. (1994). The entrepreneurs who do both: Production and rent-seeking. Journal of Economic Behavior and Organization, 23(1), 93-98. 
*Luo, G. Y. (2009). Irrationality and monopolistic competition: An evolutionary approach. European Economic Review, 53(5), 512-526.

*Martinez, M. G., Zouaghi, F., Marco, T. G., Robinson, C. (2019). What drives business failure? Exploring the role of internal and external knowledge capabilities during the global financial crisis. Journal of Business Research, 98, 441-449.

* Mata, J., \& Freitas, E. (2012). Foreignness and exit over the life cycle of firms. Journal of International Business Studies, 43(7), 615-630.

Mata, J., P. Portugal (1994), Life duration of new firms, Journal of Industrial Econom- ics, 42, 227-245.

*Mata, J., and Portugal, P. (2000). Closure and divestiture by foreign entrants: The impact of entry and post-entry strategies. Strategic Management Journal, 21(5), 549-562.

Mata, J., P. Portugal, P. Guimaraes (1995), 'The survival of new plants: Start-up conditions and post-entry evolution,' International Journal of Industrial Organization, 13, 459481.

*Murto, P. (2004). Exit in duopoly under uncertainty. RAND Journal of Economics, 111-127.

Nelson, R. R., \& Winter, S. G. (1982). An evolutionary theory of economic change. MA: Belknap press of Harvard University Press. Cambridge.

*Ovtchinnikov, A. V. (2013). Merger waves following industry deregulation. Journal of Corporate Finance, 21, 51-76.

Parastuty, Z. (2018). Systematic review of research on exit: A Bibliometric analysis and future directions. International Review of Entrepreneurship, 16(4).

*Paravisini, D., Rappoport, V., Schnabl, P., Wolfenzon, D. 2014. Dissecting the effect of credit supply on trade: Evidence from matched credit-export data. The Review of Economic Studies, 82(1): 333-359.

*Pavlov, O., and Weder, M. (2012). Variety matters. Journal of Economic Dynamics and Control, 36(4), 629-641.

*Petrakis, E., Rasmusen, E., Roy, S. (1997). The learning curve in a competitive industry. RAND Journal of Economics, 248268.

*Peyrache, A. (2013). Industry structural inefficiency and potential gains from mergers and break-ups: A comprehensive approach. European Journal of Operational Research, 230(2), 422-430.

*Plehn-Dujowich, J. M. (2009). Entry and exit by new versus existing firms. International Journal of Industrial Organization, 27(2), 214-222.

*Ponikvar, N., Kejžar, K. Z., Peljhan, D. (2018). The role of financial constraints for alternative firm exit modes. Small Business Economics, 51(1), 85-103.

* Poschke, M. (2009). Employment protection, firm selection, and growth. Journal of Monetary Economics, 56(8), 1074-1085.

*Qi, J., Sutton, N. K., Zheng, Q. (2015). The value of strategic alliances in acquisitions and IPOs. Financial Management, 44(2), 387-430.

*Raknerud, A., Rønningen, D., Skjerpen, T. (2007). A method for improved capital measurement by combining accounts and firm investment data. Review of Income and Wealth, 53(3), $397-421$.

*Rozo, S. V. (2018). Is murder bad for business? Evidence from Colombia. Review of Economics and Statistics, 100(5), 769782.
*Sakai, K., Uesugi, I., Watanabe, T. (2010). Firm age and the evolution of borrowing costs: Evidence from Japanese small firms. Journal of Banking and Finance, 34(8), 1970-1981.

*Salvato, C., Chirico, F., Sharma, P. (2010). A farewell to the business: Championing exit and continuity in entrepreneurial family firms. Entrepreneurship and Regional Development, 22(3-4), 321-348.

*Santarelli, E., Carree, M., Verheul, I. (2009). Unemployment and firm entry and exit: An update on a controversial relationship. Regional Studies, 43(8), 1061-1073.

*Saridakis, G., Mole, K., Hay, G. (2013). Liquidity constraints in the first year of trading and firm performance. International Small Business Journal, 31(5), 520-535.

Schary, M. A. (1991). The probability of exit. RAND Journal of Economics, 22(3), 339-353.

*Schröder, P. J., and Sørensen, A. (2012). Firm exit, technological progress and trade. European Economic Review, 56(3), 579591.

Sengupta, J. K. (2004). The survivor technique and the cost frontier: A nonparametric approach. International Journal of Production Economics, 87(2), 185-193.

*Serpa, J. C., and Krishnan, H. (2016). Policy incentives for dangerous (but necessary) operations. Production and Operations Management, 25(10), 1778-1798.

*Sharma, P., and Manikutty, S. (2005). Strategic divestments in family firms: Role of family structure and community culture. Entrepreneurship Theory and Practice, 29(3), 293-311.

*Siemer, M. (2019). Employment effects of financial constraints during the great recession. Review of Economics and Statistics, 101(1), 16-29.

*Sillanpää, A., and Laamanen, T. (2009). Positive and negative feedback effects in competition for dominance of network business systems. Research Policy, 38(5), 871-884.

Soto-Simeone, A., Sirén, C., \& Antretter, T. (2020). New venture survival: A review and extension. International Journal of Management Reviews, 22(4), 378-407.

Stinchcombe, A. L. (1965). Social strictures and organizations. In J. G. March (Ed.), Handbook of organizations (pp. 149-193). Rand McNally: Chicago IL.

*Sousa, C. M. P., and Tan, Q. 2015. Exit from a foreign market: Do poor performance, strategic fit, cultural distance, and international experience matter? Journal of International Marketing, 23(4): 84-104.

Sutton, J. (1997). Gibrat's legacy. Journal of Economic Literature, $35,40-59$.

*Tan, Q., and Sousa, C. M. P. 2019. Why poor performance is not enough for a foreign exit: The importance of innovation capability and international experience. Management International Review, 59(3): 465-498.

*Traù, F. (1997). Recent trends in the size structure of Italian manufacturing firms. Small Business Economics, 9(3), 273-285.

*Troske, K. R. (1996). The dynamic adjustment process of firm entry and exit in manufacturing and finance, insurance, and real estate. The Journal of Law and Economics, 39(2), 705735 .

Urbano, D., Aparicio, S., \& Audretsch, D. (2019). Twenty-five years of research on institutions, entrepreneurship, and economic growth: What has been learned? Small Business Economics, 53(1), 21-49. 
*Van Ewijk, C. (1997). Entry and exit, cycles, and productivity growth. Oxford Economic Papers, 49(2), 167-187.

*Varum, C. A., Rocha, V. C. (2012). The effect of crises on firm exit and the moderating effect of firm size. Economics Letters, 114(1), 94-97.

*Varum, C., Rocha, V. C., da Silva, H. V. (2014). Economic slowdowns, hazard rates and foreign ownership. International Business Review, 23(4), 761-773.

*Vega-Redondo, F. (1996). Technological change and market structure: An evolutionary approach. International Journal of Industrial Organization, 14(2), 203-226.

Wagner, J. (1994). The post-entry performance of new small firms in German manufacturing industries. Journal of Industrial Economics, 42(2), 141-154.

*Walsh, F. (2003). Comment on 'minimum wages for Ronald McDonald monopsonies: A theory of monopsonistic competition'. Economic Journal, 113(489), 718-722.

*Waschik, R. (2015). Differentiated products, increasing returns to scale and heterogeneous firms in a CGE model of the Australian coal sector. Energy Economics, 51, 521-529.

*Webber, M., Sheppard, E., \& Rigby, D. (1992). Forms of technical change. Environment and Planning A, 24(12), 16791709.

Wennberg, K., Wiklund, J., DeTienne, D., \& Cardon, M. (2010). Reconceptualizing entrepreneurial exit: Divergent exit routes and their drivers. Journal of Business Venturing, 25(4), 361375 .
Wennberg, K., \& DeTienne, D. R. (2014). What do we really mean when we talk about 'exit'? A critical review of research on entrepreneurial exit. International Small Business Journal, 32(1), 4-16.

*Weterings, A., Marsili, O. (2015). Spatial concentration of industries and new firm exits: Does this relationship differ between exits by closure and by M\&A? Regional Studies, 49(1), 44-58.

*Wu, J., Lao, K. F., Wan, F., Li, J. (2019). Competing with multinational enterprises' entry: Search strategy, environmental complexity, and survival of local firms. International Business Review, 28(4), 727-738.

Yamakawa, Y., \& Cardon, M. S. (2017). How prior investments of time, money, and employee hires influence time to exit a distressed venture, and the extent to which contingency planning helps. Journal of Business Venturing, 32(1), 1-17.

Yang, T., \& Aldrich, H. E. (2012). Out of sight but not out of mind: Why failure to account for left truncation biases research on failure rates. Journal of Business Venturing, 27(4), 477-492.

*Zheng, W., Singh, K., Chung, C. N. (2017). Ties to unbind: Political ties and firm sell-offs during institutional transition. Journal of Management, 43(7), 2005-2036.

Publisher's note Springer Nature remains neutral with regard to jurisdictional claims in published maps and institutional affiliations. 